\title{
Animal models of listeriosis: a comparative review of the current state of the art and lessons learned
}

\author{
Karin Hoelzer ${ }^{*}$, Régis Pouillot and Sherri Dennis
}

\begin{abstract}
Listeriosis is a leading cause of hospitalization and death due to foodborne illness in the industrialized world. Animal models have played fundamental roles in elucidating the pathophysiology and immunology of listeriosis, and will almost certainly continue to be integral components of the research on listeriosis. Data derived from animal studies helped for example characterize the importance of cell-mediated immunity in controlling infection, allowed evaluation of chemotherapeutic treatments for listeriosis, and contributed to quantitative assessments of the public health risk associated with L. monocytogenes contaminated food commodities. Nonetheless, a number of pivotal questions remain unresolved, including dose-response relationships, which represent essential components of risk assessments. Newly emerging data about species-specific differences have recently raised concern about the validity of most traditional animal models of listeriosis. However, considerable uncertainty about the best choice of animal model remains. Here we review the available data on traditional and potential new animal models to summarize currently recognized strengths and limitations of each model. This knowledge is instrumental for devising future studies and for interpreting current data. We deliberately chose a historical, comparative and crossdisciplinary approach, striving to reveal clues that may help predict the ultimate value of each animal model in spite of incomplete data.
\end{abstract}

\section{Table of contents}

1. Challenges in the study of listeriosis

2. Pathophysiology of infections with Listeria monocytogenes

3. Listeriosis in humans

3.1 Neonatal listeriosis and pregnancy-associated listeriosis

3.2 Listeriosis in adult and geriatric patients

4. Naturally occuring listeriosis among domestic and non-domestic animals

4.1 Listeriosis in ruminants

4.2 Listeriosis in monogastric mammals other than non-human primates

4.3 Listeriosis in non-human primates

4.4 Listeriosis in birds

5. Experimental infections before recognition as a foodborne disease

\footnotetext{
* Correspondence: Karin.Hoelzer@fda.hhs.gov

U.S. Food and Drug Administration, Center for Food Safety and Applied Nutrition, 5100 Paint Branch Parkway, College Park, MD 20707, USA
}

5.1 Experimental infections in non-pregnant animals

5.2 Experimental infections in pregnant animals

6. Mouse models of non-pregnancy-associated listeriosis

6.1 Susceptibility differences among mouse strains

6.2 Pathogenicity differences among L. monocytogenes strains

7. Species-specific interactions between internalines and host cells

7.1 Interactions between E-cadherin and InlA

7.2 InlB and its three receptors

8. Other animal models of non-pregnancy-associated listeriosis

8.1. Non-pregnant rat models

8.2 Non-pregnant guinea pig models

8.3 Non-pregnant rabbits as models of listeriosis

8.4 Other non-pregnant rodent models

8.5 Non-human primates as models of listeriosis

9. Animal models of pregnancy- associated listeriosis 
9.1 Non-human primates as models of pregnancy-associated listeriosis

9.2 Guinea pigs as models of pregnancy-associated listeriosis

9.3 Other rodent models of pregnancy-associated listeriosis

10. Geriatric models of listeriosis

11. Conclusions and lessons learned

11.1 Consequences for modeling L. monocytogenes dose-response

12. Competing interests

13. Authors' contributions

14. Acknowledgements

15. Endnotes

16. References

\section{Challenges in the study of listeriosis}

Listeriosis, caused by the gram-positive, facultative intracellular bacterium Listeria monocytogenes, is one of the leading causes of death due to foodborne illness in the industrialized world [1,2]. Listeriosis is a relatively rare but very serious disease, with an estimated hospitalization rate that exceeds $90 \%$ and a mortality rate of approximately $15-30 \%[1,2]$. In the United States, around 1600 human cases of invasive listeriosis occur each year, resulting in roughly 1455 hospitalizations and 255 deaths [1]. Listeriosis occurs almost exclusively in high-risk population subgroups such as pregnant women and their fetuses or infants, the elderly, or immune compromised individuals, but, as will be discussed below, clinical manifestations differ strongly among population subgroups [3-5].

Since volunteer feeding studies do not represent a viable option, the current understanding of listeriosis is mainly based on epidemiological data, clinical case reports, and the study of animal models [2,6-9]. Animal models have been of particular importance because listeriosis incidence is very low and the relatively long incubation period (i.e., average 2 to 4 weeks) complicates the reliable identification and characterization of food vehicles $[2,6,9,10]$. Optimal animal models closely resemble the respective infection process in humans, reliably lead to the infection endpoint of interest, allow for sufficient replicates to capture biological variability and to minimize uncertainty, and meet economic as well as ethical constraints. To date, no optimal animal model of listeriosis has been established and emerging knowledge about physiological differences among animal species has raised concerns about the direct relevance of most animal models for human disease [11]. Listeriosis has traditionally been studied in mice, but a variety of other species such as non-human primates, gerbils and guinea pigs have also occasionally been used and these species may prove preferable to mice [12-19]. Most studies have concentrated on pregnancy-associated disease or neonatal infection, while studies in non-pregnant adult animals have primarily focused on septicemia [12-19]. Geriatric models in species such as mice, rats and guinea pigs are available and some experiments have been performed in artificially immune suppressed animals, but as will be discussed below the extrapolation to human disease is challenging and the use of these models in the study of listeriosis has remained limited [20,21]. For these reasons it is largely unclear how relevant current listeriosis models are for meningitis and hosts with predisposing factors such as old age or immune defects.

Since the pathophysiology of infection is crucially important for the data discussed here, we will begin our review and discussion of animal models with a short summary of the pathophysiology of L. monocytogenes infection. This will be followed by a brief overview of naturally occurring clinical listeriosis in humans and different animal species and, after that, a discussion of the extensive literature on animal models of listeriosis. Since many questions about the pathogenic potential of $L$. monocytogenes in reptiles, amphibians, fish, crustaceans and other invertebrate species remain and the relevance of these models for human disease therefore appears questionable [22,23], these animals will not be explicitly discussed here even though they have occasionally been used as models of L. monocytogenes infection. Studies of listeriosis differ in host species and life stage, in whether they evaluate clinical symptoms or colonization of internal organs, and considerable experimental differences complicate comparison across studies even further. It is difficult to identify defensible, globally applicable and objective criteria by which to rank the scientific merit of these highly diverse studies. We therefore provide the reader with a comprehensive overview of the available scientific literature, synthesizing the medical, veterinary, immunological, microbiological and biomedical literature pertinent to the scientific value of animal models of listeriosis. Where possible, we point out important experimental details that may impact the interpretation of results, and, recognizing the immense variability across studies, we do not strive to make direct comparisons across studies. Therefore, wherever direct comparisons are made in the text, these are based on experiments that have been conducted as part of the same study and under identical experimental conditions if possible. We also point out instances where multiple independent studies found consistent or contradictory results. We therefore provide a synopsis of the currently available data and the weight of scientific evidence.

\section{Pathophysiology of infections with listeria monocytogenes}

Critical evaluation of the adequacy of animal models and comparisons across disease endpoints require a clear understanding of the underlying pathophysiology in humans and animals. However, numerous questions 
about the pathophysiology of infections with L. monocytogenes have remained despite longstanding concerted research efforts. The study of the pathophysiology of listeriosis has been complicated by the fact that L. monocytogenes can enter professional phagocytic cells such as dendritic cells through phagocytosis while direct entry into nonprofessional phagocytic cells, for example enterocytes or hepatocytes, is receptor-mediated, using caveolin-dependent or clathrin-mediated endocytosis, and dissemination within organs appears to occur mainly through direct, actin dependent spread from cell to cell $[6,11]$.

The intestine is the primary port of entry for L. monocytogenes, but questions about the exact mechanisms by which L. monocytogenes transgresses the intestinal barrier remain and clear differences among host species seem to exist (Figure 1) $[6,24]$. In host species deficient of functional E-cadherin such as mice (see later sections on the discovery of species-specific differences in the importance of $i n l A$ and inlB for details), L. monocytogenes is thought to translocate through the intestinal wall by gaining access into M-cells, phagocytic cells in the Peyer's patches of the ileum, despite some remaining controversies about the details of this process [24-27]. In species such as humans or guinea pigs that possess functional E-cadherin, L. monocytogenes is on the contrary, thought to primarily invade the epithelium of the intestinal villi, followed by bacterial replication in the underlying lamina propria $[24,28]$. L. monocytogenes then rapidly translocates across the intestinal barrier, without a need for bacterial replication in the intestinal wall, so that bacteria often reach the liver and spleen within minutes of oral inoculation [6]. However, extensive bacterial replication in the intestinal wall can occur during the intestinal phase of infection, and in these cases bacteria appear to move among cells of the intestinal wall via direct spread, caused by actin polymerization that is mediated by L. monocytogenes virulence factor ActA $[6,28,29]$. The development of lasting mucosal immunity in response to infections with L. monocytogenes is currently still subject to debate [30]. However, in the intestinal wall, the presence of L. monocytogenes stimulates dendritic cells, resident macrophages and lymphocytes, and leads to an increase in the levels of Th1-type cytokines, NF-kB, and interleukin-15 (IL-15) [6,25,31-33]. Immune responses are therefore clearly already elicited during the intestinal stage of infection.

After crossing the intestinal barrier, L. monocytogenes spreads to the liver, spleen and mesenteric lymph nodes, probably at least partially inside infected dendritic cells $[6,24,33]$. The majority of the invading bacteria become trapped in the liver and are therefore rapidly cleared from the circulatory system, followed by inactivation through immune cells such as Kupffer cells, other mononuclear phagocytic cells, neutrophils, dendritic cells and natural killer cells even though many aspects of this process have so far remained elusive [34,35]. Surviving bacteria replicate in hepatocytes, but questions about the mechanisms by which L. monocytogenes gains entry into these cells remain [6]. In host species with functional MetC receptors such as humans or mice (see later sections on the discovery of species-specific differences in the importance of $i n l A$ and inlB for details), L. monocytogenes appears to directly invade hepatocytes, probably through the Disse space after penetrating the endothelium that lines the liver sinusoids [6,36-39]. In other species, for instance guinea pigs, that do not possess functional MetC receptors, $L$. monocytogenes is thought to invade hepatocytes through cell-to-cell spread from infected Kupffer cells [6,37]. Further dissemination of L. monocytogenes within the liver parenchyma probably again occurs through direct, actin-mediated cellto-cell spread [6]. Infected hepatocytes respond to infection with $L$. monocytogenes by secreting chemoattractants that recruit neutrophils to the site of infection and by initiating apoptosis, resulting in the development of typical multifocal granulomas in the liver parenchyma [6].

The remaining circulating bacteria are rapidly cleared through resident macrophages in the spleen, even though inactivation may be less efficient than in the liver and extensive bacterial replication occurs in the liver and spleen during early stages of infection $[6,40]$. Notably, the spleen plays a dual role in $L$. monocytogenes pathophysiology; despite initially increasing susceptibility to infection, the spleen is indispensable for the development of subsequent adaptive immune responses [41]. L. monocytogenes is initially ingested by macrophages and dendritic cells located in the marginal zone of the spleen, followed by translocation into the white pulp $[42,43]$. In the white pulp, L. monocytogenes induces wide-spread apoptosis, accompanied by the development of microscopic abscesses consisting of macrophages, neutrophils and apoptotic lymphocytes [44]. This process appears to be required for priming anti-Listeria cytotoxic T-cell (CTL) responses [41]. In species that possess functional MetC receptors, $L$. monocytogenes also appears to be able to enter splenocytes in an inlB-dependent manner, but the precise mechanisms have so far not been revealed [45].

If the infection is not controlled at this stage, for instance because of severe immune suppression, a secondary bacteremia develops, followed by dissemination of L. monocytogenes to a variety of secondary organs [6]. During this process L. monocytogenes can gain access to sanctuary sites by transgressing the blood-brain barrier or the placental barrier in pregnant hosts. Numerous questions about the exact mechanisms by which L. monocytogenes transgresses these barriers remain $[6,46]$. L. monocytogenes appears capable of directly invading endothelial cells including those located in the blood-brain barrier in an inlB-dependent manner, but in MetC 


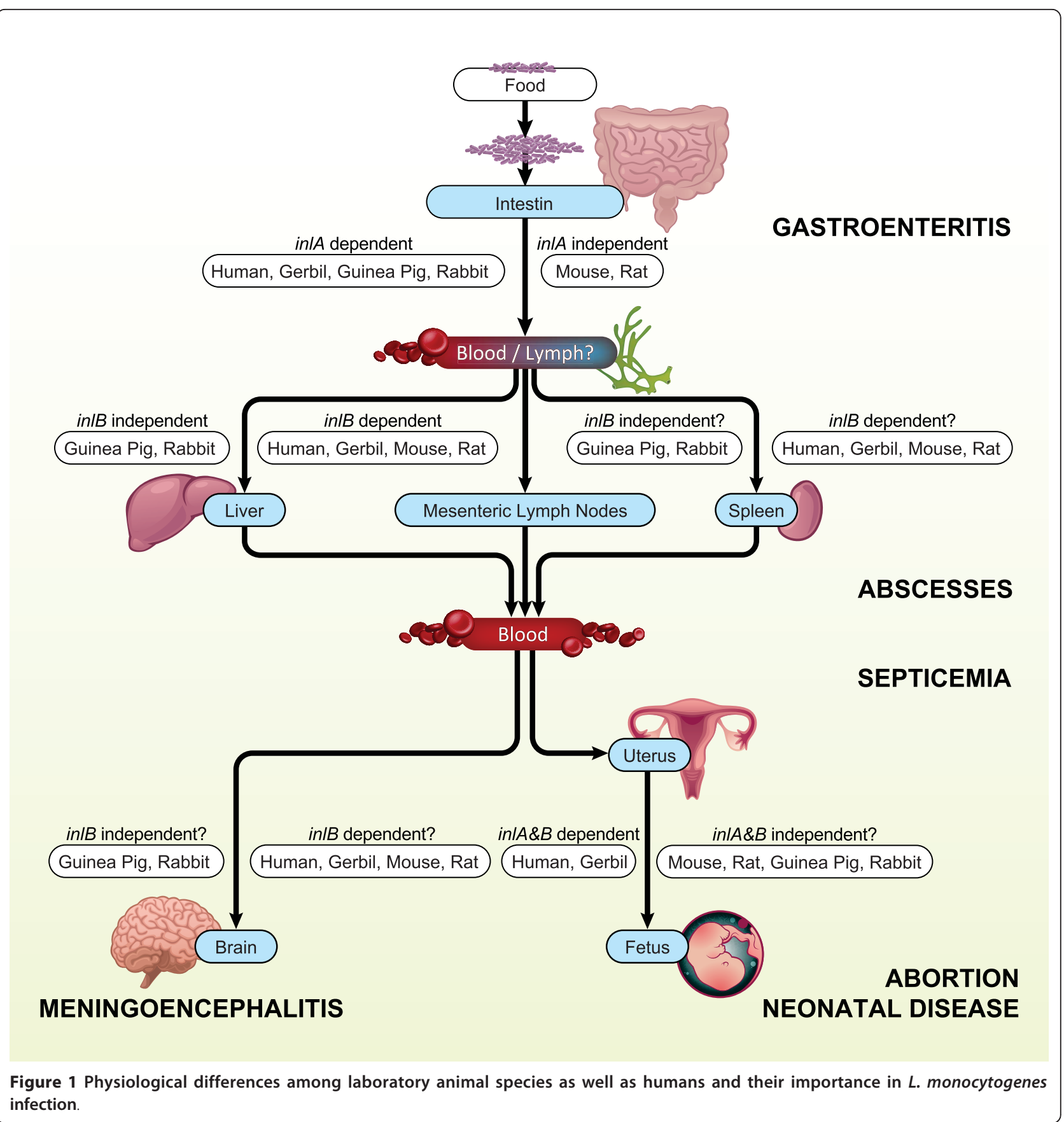

deficient species, entry into endothelial cells probably occurs indirectly, mediated by direct cell-to-cell spread from phagocytic cells such as macrophages [47-51]. L. monocytogenes can replicate within endothelial cells and probably directly spreads to neighboring cells in an ActA dependent manner [50]. While L. monocytogenes is capable of directly invading neuronal cells, invasion of neurons in the central nervous system is thought to predominantly occur through direct spread from infected macrophages or microglial cells [47]. Infected macrophages may also play a direct role in transgressing the blood-brain barrier through a so-called "Trojan-horse" mechanism [52]. Many questions about how L. monocytogenes transgresses the placental barrier have so far also remained unanswered, but bacteria can probably cross the endothelium of the maternal blood vessels, followed by entry into the fetal circulatory system of the placental villi [6]. In animal species that possess both functional $\mathrm{E}$-cadherin and MetC, this process appears to be both InlA and InlB dependent [12]. In species deficient in either of these receptors, however, 
crossing of the placental barrier appears neither InlA nor InlB dependent, and presumably occurs through direct cell-to-cell spread $[12,53]$ (see section on pregnant animal models for further details on the impact of pregnancy on listeriosis). Clinical listeriosis generally develops as L. monocytogenes spreads to and invades secondary organs, predominantly the brain and placenta.

\section{Listeriosis in humans}

\subsection{Neonatal listeriosis and pregnancy-associated listeriosis}

Pregnancy-associated cases are thought to contribute to between 16 and $27 \%$ of invasive listeriosis cases, and often result in abortion, stillbirth or premature labor [54]. Since cases of spontaneous abortion or stillbirth are not routinely tested for listeriosis the fraction of fetal losses attributable to listeriosis is currently unknown, but the fetal mortality rate among women diagnosed with listeriosis is thought to be between 16 and 45\% [55]. Listerial infection of the mother during pregnancy is often but not always associated with infection of the fetus [56,57]. One literature review, for instance, found that $20 \%$ of reported pregnancy - associated cases resulted in spontaneous abortion or stillbirth and $68 \%$ of the remaining cases (i.e., $54 \%$ of all pregnancy-associated cases) resulted in neonatal infection, indicating that fewer than $30 \%$ of pregnancy-associated cases neither led to abortion or stillbirth nor to neonatal infection $[55,58]$. Even though possible at any point during pregnancy, listeriosis is most frequently reported during the third trimester [2]. Clinical manifestations, apart from mild flu-like prodromal symptoms, are rarely reported in otherwise healthy women, but complications such as meningoencephalitis or endocarditis have occasionally been described, primarily in pregnant women with preexisting comorbidities $[2,54,59]$. Purulent villitis and microabscesses are common histopathological findings in the placentas of pregnancy-associated cases, occasionally associated with chorioamnionitis [60]. Twin pregnancies may potentially be associated with an increased risk of listeriosis, but the underlying biological determinants so far remain largely unclear [61].

Two distinct forms of listeriosis are recognized among neonates. Early onset disease, caused by infection in utero, occurs during the first week of life [2]. Neonates are often delivered pre-term, with low birth weight, and present septicemia, pneumonia, and occasionally meningitis during the first days of life $[2,60,62]$. Pustular skin lesions and multifocal microabscesses in the lungs, liver and spleen of affected infants are pathognomonic findings in early onset listeriosis, causing this manifestation to be commonly referred to as "granulomatosis infantiseptica" $[60,61]$. Early onset listeriosis has a poor prognosis, with a case-fatality rate of $20-30 \%$, and surviving infants often develop sequelae [59].
Late onset disease, on the contrary, is typically characterized by meningitis, sometimes accompanied by other symptoms such as fever, colitis and diarrhea [62]. This manifestation generally occurs in infants 7 to 20 days after birth [61]. In these cases, pregnancy was usually uneventful, carried to term, and infants appeared healthy at birth [59]. The source of infection often remains unclear, but perinatal infections through contact with the birth canal, maternal feces, or the home environment have been suggested, as well as nosocomial transmissions [59,62-65]. Case-fatality rates for late onset listeriosis have been estimated at approximately $10 \%$, and neurological sequelae have occasionally been described in surviving infants [61].

\subsection{Listeriosis in adult and geriatric patients}

Meningitis or meningoencephalitis and septicemia are the most common clinical manifestations of invasive listeriosis in adults and are generally associated with comorbidities such as malignancies, immunosuppressive therapies, alcoholism, hepatopathies, renal failure, HIV infection, diabetes mellitus, autoimmune disorders or hemochromatosis [61,66-68]. Septicemia occurs in an estimated $21-43 \%$ of cases, and is often manifested as fever, nausea, vomiting and myalgia [66]. These conditions can be complicated by disseminated intravascular coagulation, respiratory distress and multi-organ failure [66].

Headache, nausea, high fever, stiff neck, confusion, lethargy and less frequently ataxia, tremor and seizures are typical clinical symptoms associated with listerial meningitis or meningoencephalitis $[66,68,69]$. Typical histopathological findings include suppurative meningitis with purulent exudate concentrated around the brain stem, and white-gray foci of microabscesses in the meninges and occasionally brain cortex [69]. In approximately $10 \%$ of cases, L. monocytogenes affects the cortex parenchyma, resulting in encephalitis and abscess formation which is typically manifested as cognitive dysfunction and altered consciousness [68]. Histological findings in the brains of patients with listerial encephalitis include perivascular microabscesses, multifocal vasculitis, and perivascular cuffing [69]. Case - fatality rates of $15-27 \%$ have been reported for listerial meningitis or meningoencephalitis and casefatality rates of up to $59 \%$ have been mentioned for L. monocytogenes brain abscesses $[67,68]$.

In healthy adults, listeriosis is typically manifested as gastroenteritis, a mild, self-limiting condition characterized by fever, diarrhea, abdominal cramps, nausea and vomiting, headache, myalgia and arthralgia $[2,70]$. However, rhombenchephalitis, a rare but very severe form of listerial encephalitis, also occurs predominantly in adults without classical comorbidities $[61,71]$. Rhombenchepahlitis is characterized by a typical biphasic course - a prodromal stage with flu-like symptoms such as fever, headache, 
myalgia, nausea and vomiting, followed by the sudden onset of unilateral or bilateral paralysis of cranial nerves, ataxia, vertigo and impaired consciousness [61,71]. Death often occurs due to respiratory or cardiac failure, and sequelae are common in survivors [71]. Perivascular cuffing and microabscesses in cerebellum and medulla oblongata are common associated histological findings [61,71].

A variety of atypical manifestations of listeriosis, involving for instance the eye, joints, bones, heart or skin have also been documented in rare cases, and cutaneous infections represent occupational hazards for veterinarians during obstetric manipulations [55,72].

\section{Naturally occuring listeriosis among domestic and non-domestic animals}

L. monocytogenes was first described by Murray et al. in 1926 who isolated the bacterium from the livers of clinically sick rabbits and guinea pigs [23,73]. Since then listeriosis has been recognized as a disease of mammals and birds, and as a potential zoonosis [6,74-77]. During the 1980s several large outbreaks among humans led to the recognition of $L$. monocytogenes as an important foodborne pathogen, shifting the focus from a veterinary to a human public health problem $[6,78]$.

\subsection{Listeriosis in ruminants}

Even though $L$. monocytogenes can infect a wide variety of animal species, listeriosis is primarily a clinical disease of ruminants, which can also be caused by L. ivanovii, a Listeria species non-pathogenic for humans and other animal species $[23,55]$. Sheep appear to be particularly susceptible to infection, but listeriosis is also common in a variety of other polygastric species and L. monocytogenes has for instance been isolated from cattle, goats, llamas, alpacas, deer, reindeer, antelopes, water buffalos and moose $[23,55,79-81]$. It is worth mentioning that bacterial shedding in the absence of clinical symptoms has occasionally been observed $[55,82,83]$.

Listeriosis represents one of the most common etiologies for encephalitis among adult ruminants [55]. Ruminants affected by encephalitis generally show marked neurological symptoms including ataxia, "circling", opisthotonus, and paralysis of cranial nerves, combined with hyperthermia, anorexia and depression [84]. Encephalitis is the most common clinical manifestation of listeriosis in ruminants, while large epidemics of third trimester abortions, typically manifested as stillbirth, as well as atypical manifestations such as conjunctivitis have also repeatedly been described $[55,84,85]$. With the exception of neonates and young ruminants, septicemia is unusual, but can result in mastitis, gastro-enteritis, hepatitis, or pneumonitis $[55,86]$. Notably, in a given affected herd listeriosis generally exhibits a single clinical manifestation $[55,86]$.
Listeriosis occurs seasonally among ruminants, with the highest incidence in winter and early spring, and appears strongly associated with ingestion of spoiled silage $[55,87]$. It has been suggested that $L$. monocytogenes may cause rhombencephalitis in ruminants through centripetal migration along cranial nerves, particularly the trigeminal nerve, followed by multiplication in pons and medulla oblongata $[6,55]$. Consistent with this hypothesis, changes in dentation and other lesions in the oral cavity as well as on the lips, nostrils or conjunctiva appear to be predisposing factors for listeriosis in ruminants [55]. Typically, histopathological findings in ruminants with rhombencephalitis are unilateral, located in the brain stem, particularly pons and medulla oblongata, and include perivascular cuffing and multifocal microabscesses, generally without involvement of meninges or choroid plexus $[55,84,88]$. These lesions clearly resemble those observed in humans affected by rhombencephalitis [88]. Septicemic cases among ruminants are characterized by multifocal necrosis of the liver, spleen, and potentially other organs [55,84]. Placentitis and endometritis are typical findings associated with abortions [84].

\subsection{Listeriosis in monogastric mammals other than non- human primates}

Clinical listeriosis is relatively rare in most monogastric mammals such as dogs, cats, horses and pigs, but appears more common in rodents and lagomorpha, where listeriosis was first described $[23,73,79]$. Notably, L. monocytogenes has also been isolated from clinically healthy monogastric mammals $[55,82]$. Listeriosis in monogastric mammals is typically manifested as septicemia $[55,89]$. Abortion, meningoencephalitis and other manifestations such as conjunctivitis are also possible, but their relative frequency differs by animal species $[55,90]$. Large outbreaks of listeriosis have been reported among colonies of captive rodents and lagomorpha, including chinchillas, rabbits, rats and guinea pigs [55]. Contaminated feed such as hay or sugar beets was implicated as the outbreak vehicle in many of these outbreaks, and coprophagy may have contributed to some of the outbreaks [55]. L. monocytogenes has also been isolated from a variety of other rodents and lagomorpha including gerbils, bush-tailed jirds, mountain hares, European hares, Japanese hares, voles, field mice, muskrats, shrews, capybaras, and squirrels, as well as rock hyrax and other mammals in zoological exhibits, but the association with clinical disease is not in all cases clear [23,91-100]. In some of the outbreaks reported among rodents and lagomorpha disease progression was peracute, and death occurred prior to the development of pronounced pathological lesions $[55,101]$. In other cases septicemia and neurological symptoms such as torticollis and ataxia dominated, even though metritis and abortion have also been described $[102,103]$. For currently unknown 
reasons chinchillas and rabbits appear particularly susceptible to infection [73,101,103-105]. Abortion and metritis are quite common, especially in chinchillas, and are often associated with gastro-intestinal symptoms such as diarrhea, constipation, intestinal invaginations or prolapsed rectum [104]. Common histophathological lesions include multifocal necrosis of the liver and necrotizing endometritis $[94,102]$.

\subsection{Listeriosis in non-human primates}

A small number of listeriosis cases among captive nonhuman primates have been described [106-108]. In addition, $L$. monocytogenes has been isolated from feces of wild monkeys in Japan and Listeria from the blood of wild baboons in Africa, but the absence or presence of clinical symptoms in the animals was not reported and in the latter case the Listeria species was not identified $[96,109]$. Clinical manifestations of listeriosis as septicemia, meningoencephalitis and abortion have been observed in captive non-human primates, with reported neurological symptoms including stiffness of the neck and paralysis of the facial nerves [106,108,110,111]. Post-mortem examination of a non-human primate affected by purulent meningoencephalitis revealed perivascular cuffing and mononuclear cell infiltration, while focal hepatic necrosis and placentitis were reported in a case of perinatal septicemia, and necrosis of the placental villi as well as multifocal necrosis of several fetal organs was described in a case of abortion $[107,108,110]$.

\subsection{Listeriosis in birds}

Clinical listeriosis in birds is rare, and seems to frequently represent a secondary infection which has been associated with a variety of viral, bacterial or parasitic diseases as well as tumors $[23,55]$. Young birds are more susceptible to disease than adult birds, and susceptibility differs among avian species $[23,76]$. L. monocytogenes has been isolated from a wide variety of domestic and wild birds including chickens, geese, ducks, turkeys, pigeons, canaries, parrots, eagles, owls and partridges [76]. Similar to observations in mammals, bacterial shedding in the absence of clinical symptoms has occasionally been described [23]. Disease in birds is most commonly manifested as septicemia, resulting in focal necrosis of the liver, spleen, heart, kidneys, lungs, air sacks, intestine, oviduct or cornea $[23,76]$. Listerial meningoencephalitis is uncommon among birds $[23,55]$. Affected fowl exhibit typical central nervous system symptoms including torticollis, tremor, and paralysis of the legs or wings [23,55]. Post-mortem examination of affected birds often reveals perivascular cuffing and focal necrosis in the cerebellum and medulla oblongata, which is frequently accompanied by septicemic lesions in the liver and spleen [55].

\section{Experimental infections before recognition as foodborne disease}

\subsection{Experimental infections in non-pregnant animals}

The first report of experimental inoculations with L. monocytogenes, in rabbits, dates back to the first study describing this pathogen in 1926 [73]. In the following decades, before L. monocytogenes was recognized as a major foodborne pathogen, numerous animal experiments were performed in a large variety of species including mice, rats, rabbits, guinea pigs, dogs, cats, pigs, ruminants and non-human primates [23]. Because pathogenesis and in prticular infection routes were essentially unknown, studies often compared a large number of exposure routes (e.g., oral, gastric, intraveneous, intraperitoneal, intracerebral, subcutaneous, submucosal, conjunctival, vaginal and nasal), and different studies occasionally reported seemingly contradictory results $[23,112,113]$. Notably, it is extremely difficult to experimentally produce listeriosis in non-pregnant animals that resembles naturally occurring disease proves extremely difficult [23]. Encephalitis or meningoencephalitis are extremely difficult to evoke unless bacteria are instilled directly in the cerebrum, partially because animals tend to die before meningitis can develop [23]. Intravenous, intraperitoneal and intracerebral routes of exposure reliably lead to disease in non-pregnant animals, but their relevance for naturally occurring disease appears questionable [23]. Respiratory routes of infection using aerosolized inoculum are generally efficient means of inoculating non-pregnant mice, guinea pigs, hamsters, rabbits, piglets and non-human primates, and in many experiments animals succumbed to septicemia [23,75, $114,115]$. In experimental infections, non-human primates developed pyrexia but recovered from aerosol exposure and gross septicemic lesions were absent upon post-mortem examination of sacrificed animals, even though some animals mounted a humoral immune response after inoculation and bacteria could be isolated from the blood of some animals post inoculation $[23,115]$. Except for chinchillas and certain strains of mice, oral exposure, even at high dose, rarely leads to disease in non-pregnant animals, with the exception of very young animals [23]. However, successful oral inoculation after starvation has occasionally been reported [116]. Remarkably but consistent with observations from naturally infected animals, in some instances bacteria can be isolated from experimentally inoculated animals in the absence of clinical symptoms or pathological lesions, albeit bacterial concentrations are likely low since cultures had to be kept at refrigerated temperatures for several weeks to culture L. monocytogenes from the animal tissues, thereby hampering the growth of background microflora and allowing the psychotropic bacteria to 
reach numbers sufficient for detection [23,117]. Ocular inoculation produces conjunctivitis and other eye infections in non-pregnant animals of various species including rabbits, guinea pigs and non-human primates, and exposed animals occasionally develop septicemia, meningitis or meningoencephalitis [23,118-120]. Non-human primates mostly develop mild and transient ocular symptoms while guinea pigs and rabbits develop severe symptoms and occasionally succumb to systemic infection [120]. Irrespective of exposure route or animal species, inoculation of non-pregnant animals often leads to generalized septicemia, even in ruminants, and sustained septicemia occasionally - though not reproducibly results in meningitis or meningoencephalitis $[23,113]$.

Importantly, the clinical manifestation of experimental infection appears highly dose-dependent; high inoculation doses tend to lead to peracute death without visible involvement of the central nervous system $[23,113,115]$. Focal necrosis of the liver with infiltration of mononuclear cells is a typical histopathological finding in septicemic animals, sometimes also affecting the spleen, lungs, and other organs such as the tonsils, intestinal tract or adrenal glands $[23,113,121]$. In general, susceptibility to infection differs with $L$. monocytogenes strain, inoculation dose, age group - with suckling mice particularly susceptible to infection-, animal species and also immune status $[23,75,115,122]$. For example, it was found that injecting mice with Bacillus Calmette-Guérin (BCG, a vaccine against tuberculosis) prior to L. monocytogenes challenge increases resistance to listeriosis, while experimentally induced stress reduces resistance, at least in hamsters, guinea pigs and possibly in lemmings [75,123]. Guinea pigs, hamsters, dogs, cats and pigs overall appear considerably more resistant to infection than rabbits and mice; in guinea pigs focal necrotic lesions appear atypical in that they are often limited to the myocardium $[23,115,123]$.

\subsection{Experimental infections in pregnant animals}

Pregnancy-associated listeriosis has been studied in ruminants and several monogastric species using a variety of exposure routes [23]. Regardless of placentation type, gestational stage and exposure route, experimental inoculation of pregnant animals often results in abortion $[23,122,124]$. Oral inoculation efficiently produces abortion, as demonstrated for example in pregnant rabbits and goats [23]. Perinatal infection through vaginal contamination was also shown to be possible, but rarely occurs even under experimental conditions $[23,113]$. In guinea pigs and rabbits abortion following conjunctival challenge has also been reported [23,122,124].

Clinical manifestations clearly differ by gestational stage at the time of inoculation and infectious dose [122,124]. Placentitis, endometritis and focal necrosis are common findings in aborted animals, and live borne animals often succumb to septicemia or meningoencephalitis, depending on the length of the time interval between birth and the onset of disease symptoms [23,122]. Placentitis and the resulting nutritional limitations for the fetus seem to play a major role in the development of abortion. In the placentas of experimentally infected rats necrotic lesions are predominantly focused in the junctional zone of the placental disc, but often extend to the labyrinth and metrial glands, and maternal sinuses are infiltrated with monocytes and polymorphic cells [23,125]. Importantly, crossing of $L$. monocytogenes through the placental barrier in the absence of placental lesions has also been described $[23,126]$.

\section{Mouse models of non-pregnancy-associated listeriosis}

Since the identification of $L$. monocytogenes as a major human food-borne pathogen in the early 1980s, considerable attention has been devoted to oral or intragastric routes of exposure. Infection through the oral route is thought to be the most relevant for humans but poses considerable practical challenges. For a long time, mice and to a lesser extent rats were the most popular species used to establish oral models of listeriosis, predominantly evaluating septicemic death $[11,27,127,128]$. The development of invasive disease in these animals is dosedependent, but in adult animals relatively high doses are often required to invoke disease and death $[11,127,128]$. Despite these limitations, murine and rat models have proved instrumental in elucidating key aspects of L. monocytogenes infection and immunity, and for instance have allowed establishment of a correlation between reduced gastric acid levels and increased susceptibility to infection, which had been suggested through epidemiological studies in humans [128-130]. Due to the difficulty of reproducibly invoking and monitoring disease in mice after experimental inoculation, death was often chosen as the study endpoint and the dose at which $50 \%$ of inoculated mice died (i.e., median lethal dose, or $\mathrm{LD}_{50}$ ) was commonly used to compare results across studies. Other study outcomes such as bacterial concentrations in different organs or ratios of different $L$. monocytogenes strains used in the inoculum cocktail (i.e., competitive indexing), which represent commonly chosen study outcomes in most other animal species, have occasionally been used in mouse studies of listeriosis. As reported above, neurological symptoms have proven particularly difficult to evoke experimentally. However, repeated oral challenge of mice with sublethal doses (i.e., $5 \times 10^{9} \mathrm{cfu}$ ) has been shown to lead to the establishment of CNS symptoms, at least in some of the animals [131]. Notably, repeated dosing over a longer time period (i.e., 10 vs. 7 consecutive days) appears to result in a somewhat higher prevalence of CNS 
symptoms while dosing for less than 5 days does not result in the development of clinical CNS symptoms, emphasizing the potentially paramount importance of multiple dosing [131].

\subsection{Susceptibility differences among mouse strains}

The susceptibility of mice to L. monocytogenes infection is affected by the physiological state of the animal and differs considerably among mouse strains [132-140]. $\mathrm{LD}_{50}$ values for different mouse strains and exposure routes often differ by several orders of magnitude (Table 1), even though differences in experimental design (e.g., inoculums size, preparation and quantification of inoculum, animal sex and age group, number of days of follow-up after inoculation, L. monocytogenes strain used for inoculation, use of bicarbonate treatment, starvation or immune suppression prior to inoculation, method of $\mathrm{LD}_{50}$ calculation, etc.) complicate comparison across studies. Mice of strains A/J or $\mathrm{BALB} / \mathrm{c}$, for example, are considerably more susceptible to intragastric as well as intraveneous and intraperitoneal infection than mice of strain $\mathrm{C} 57 \mathrm{BL} / 6$, with reported intragastric $\mathrm{LD}_{50}$ values equaling $10^{6}$ and $10^{8} \mathrm{cfu}$ for mice of strains A/J and C57BL/6, respectively [137,138,141].

The physiological or immunological determinants of these susceptibility differences have so far only been partially elucidated. After bicarbonate treatment, mice of strains BALB/c and C57BL/6 developed more marked gastric and intestinal lesions in response to oral inoculation with $10^{9} \mathrm{cfu}$ L. monocytogenes than mice of strains ICR, $\mathrm{C} 3 \mathrm{H}$ and $\mathrm{FVB}$, potentially indicating mouse strain-specific differences during the intestinal phase of infection [162]. Certain mouse strains probably also differ in the ability to control infection in the liver since differences in the size and frequency of hepatic lesions between mice of susceptible strain BALB/c and resistant strain $\mathrm{C} 57 \mathrm{BL} / 10$ have been described [163].

Susceptibility differences are at least partially genetically determined: mice of strain C57BL/6 and related sublines NZB and SJL appear considerably more resistant to intravenous inoculation than mice of strains $A / J, B A L B / c$ or $\mathrm{CBA}$, and $\mathrm{LD}_{50}$ values equaling $9 \times 10^{5}$ and $4-8 \times 10^{3}$, respectively, have been reported [138]. Back-crossed $(\mathrm{C} 57 \mathrm{BL} / 6 \times \mathrm{BALB} / \mathrm{c})$ mice, on the contrary, showed intermediate susceptibility with $\mathrm{LD}_{50}$ values in the range of $3.4 \times 10^{4} \mathrm{cfu}$ [138]. Notably, the degree of susceptibility to infection also varies among individual back-crossed animals, possibly indicating that susceptibility differences are controlled by multiple genetic loci $[138,164]$. Many laboratory mice strains are intentionally bred for their distinctive immunological characteristics, and these immunological differences probably represent one of the key determinants of susceptibility differences to L. monocytogenes infection. Susceptibility of the A/J strain and certain other strains such as DBA/2, for instance, appears to be linked to allelic variation in the $\mathrm{Hc}$ locus, which controls complement C5 levels in the mouse $[133,164,165]$. Yet, other L. monocytogenes susceptible mouse strains such as BALB/c are C5sufficient, strongly suggesting the presence of additional susceptibility determinants [133].

Differential cytokine expression during infection likely contributes to susceptibility differences among inbred mice strains. After intravenous inoculation with $6 \times 10^{3}$ cfu of L. monocytogens, interleukin transcription levels, in particular IL-12 and IL-15, were higher in dendritic cells from spleens of $\mathrm{C} 57 \mathrm{BL} / 6$ mice than in dendritic cells from spleens of BALB/c mice [166]. Mice of strain C57BL/6 also expressed higher INF- $\gamma$ and GM-CSF levels in the spleen shortly after infection than mice of strain A/J, even though levels in the liver appeared similar [167]. Differences in susceptibility between C57BL/6 substrains C57BL/6 J and C57BL/6By after intravenous L. monocytogenes inoculation have been linked to differential IfnbI expression, with increased IFN $\beta$ levels increasing susceptibility to infection, thus emphasizing the potentially important role of cytokine expression in strain susceptibility [132].

Sex may directly impact susceptibility of adult mice to L. monocytogenes infection, potentially due to differences in IL-10 expression, even though contradictory results have been reported [168]. Pasche et al., for instance, showed that, based on survival time differences after challenge, female mice of strains BALB/c, C57BL/6, C3H/HeN and $\mathrm{CBA} / \mathrm{J}$ were significantly more susceptible to intravenous inoculation than concurrently inoculated male mice of the same strains, with associated p-values ranging from 0.002 to 0.05 for the different strains [168]. MainouFolwer, on the contrary, did not detect significant differences in $\mathrm{LD}_{50}$ values between male and female mice of $\mathrm{BALB} / \mathrm{c}$ or $\mathrm{C} 57 \mathrm{BL} / 6$ strains after intraveneous inoculation [139], and Cheers and McKenzie did not detect marked differences in survival between male and female mice of various strains including BALB/c, CBA and C57BL/6 [138].

Age significantly impacts susceptibility to infection. For instance, $\mathrm{LD}_{50}$ values for specific pathogen free (SPF) sucking mice of strain ddY after intragastric inoculation have been shown to be approximately $10^{5} \mathrm{cfu}$ lower than those for 5 week old SPF animals of the same strain [127]. Pine et al. demonstrated approximately 10 fold differences in susceptibility of 21 compared to 33 day old female mice of strain NCR after intragastric L. monocytogenes inoculation, regardless of the L. monocytogenes strain used [17]. Backcrossed (A/Tru $\times$ C57BL/6) mice 1, 8 and 24 months of age exhibited $\mathrm{LD}_{50}$ values of $1.6 \times$ $10^{4}, 4.0 \times 10^{6}$ and $1.6 \times 10^{5} \mathrm{cfu}$, respectively, when inoculated intravenously with $L$. monocytogenes strain EGD, even though age differences were not observed when mice were inoculated with low bacterial doses [144]. 
Table 1 Susceptibility of some mouse strains used as models of non-pregnancy-associated $L$. monocytogenes infection, measured as median lethal dose $\left(\right.$ LD $\left._{50}\right)$

\begin{tabular}{|c|c|c|c|c|c|c|c|}
\hline \multirow[t]{3}{*}{ mouse strain } & \multicolumn{6}{|c|}{$\mathrm{LD}_{50}$ range (in $\mathrm{CFU}$ ) reported in the literature } & \multirow{3}{*}{$\begin{array}{l}\text { Recognized mouse } \\
\text { phenotype }\end{array}$} \\
\hline & \multicolumn{2}{|l|}{ oral/intragastric } & \multicolumn{2}{|l|}{ intravenous } & \multicolumn{2}{|l|}{ intraperitonial } & \\
\hline & $\mathrm{LD}_{50}$ (strain) & Reference & $\mathrm{LD}_{50}$ (strain) & Reference & $\mathrm{LD}_{50}$ (strain) & Reference & \\
\hline $\mathrm{A} / \mathrm{J}$ & $10^{6}(\mathrm{a})$ & [137] & $10^{3}(b, d)$ & {$[138,141]$} & $<10^{7}-10^{11}(b, d, e, i)$ & {$[142,143]$} & susceptible \\
\hline $\mathrm{A} / \mathrm{Tru} \times \mathrm{C} 57 \mathrm{~B} \mathrm{~B} / 6^{7}$ & & & $10^{4}(b)$ & [144] & & & - \\
\hline $\mathrm{A} / \mathrm{Tru} \times \mathrm{C} 57 \mathrm{~B} \mathrm{~B} / 6^{4}$ & & & $10^{6}(\mathrm{~b})$ & [144] & & & - \\
\hline $\mathrm{A} / \mathrm{Tru} \times \mathrm{C} 57 \mathrm{~B} \mid / 6^{8}$ & & & $10^{5}(b)$ & [144] & & & - \\
\hline A/WySn & & & $10^{4}(\mathrm{~d})$ & [138] & & & - \\
\hline \multirow[t]{3}{*}{$\mathrm{BALB} / \mathrm{C}$} & & & $10^{3}(b, d)$ & {$[138,145]$} & $10^{5}$ (i) & [147] & susceptible \\
\hline & & & $10^{4}(\mathrm{c})$ & {$[146]$} & & & \\
\hline & & & $10^{5}(\mathrm{f}, \mathrm{i})$ & [139] & & & \\
\hline B10.A & & & $10^{5}(b, d)$ & {$[138,141]$} & & & resistant \\
\hline B10.D2/Sn & & & $10^{5}(b, d)$ & {$[138,141]$} & & & resistant \\
\hline CBA & & & $10^{3}(\mathrm{~d})$ & [138] & & & susceptible \\
\hline C3HeB/FeJ & & & & & $10^{4}(\mathrm{i})$ & {$[148]$} & susceptible \\
\hline \multirow[t]{3}{*}{ C57BL/6 } & $10^{3}(\mathrm{~b})$ & [145] & $10^{3}(\mathrm{~b})$ & [145] & & & resistant \\
\hline & $10^{8}(\mathrm{a})$ & [137] & $10^{5}(b)$ & [149] & & & \\
\hline & $>10^{10}(b)$ & [149] & $10^{6}(\mathrm{~d}, \mathrm{f}, \mathrm{i})$ & {$[138,139]$} & & & \\
\hline \multirow[t]{2}{*}{$\mathrm{C} 57 \mathrm{BL} / 6 \times \mathrm{BALB} / \mathrm{C}$} & & & $10^{3}(\mathrm{~b})$ & {$[42]$} & & & intermediate \\
\hline & & & $10^{4}(d)$ & [138] & & & \\
\hline $\mathrm{C} 57 \mathrm{BL} / 6 \times \mathrm{DBA} / 2 \mathrm{~N}$ & & & $10^{4}(b)$ & [150] & $10^{7}-10^{9}(\mathrm{~b}, \mathrm{e}, \mathrm{i})$ & [143] & intermediate \\
\hline C57BL/10Sn & & & $10^{5}(\mathrm{~b})$ & [141] & & & resistant \\
\hline $\mathrm{DBA} / 2 \mathrm{~J}$ & & & $10^{3}(\mathrm{~b})$ & [141] & & & susceptible \\
\hline$d d Y^{3}$ & $10^{4}(\mathrm{~g})$ & [127] & & & & & - \\
\hline$d d Y^{4}$ & $>10^{9}(\mathrm{~g})$ & [127] & & & & & - \\
\hline \multirow[t]{3}{*}{ ICR } & & & $10^{5}(\mathrm{~d})$ & [151] & $10^{4}-10^{7}(a, d, e, i)$ & [152] & intermediate \\
\hline & & & & & $10^{4}->10^{8}(b, d, i)$ & {$[19,153]$} & \\
\hline & & & & & $10^{5}->10^{9}(a, d, e, i)$ & [154] & \\
\hline $\begin{array}{l}\text { Inbred white } \\
\text { (Washington State } \\
\text { University) }\end{array}$ & & & & & $10^{5}-10^{7}(\mathrm{c})$ & [155] & - \\
\hline$N C R^{1}$ & $10^{1}-10^{5}(\mathrm{~d}, \mathrm{e}, \mathrm{i})$ & {$[17]$} & & & $10^{1}-10^{5}(\mathrm{~d}, \mathrm{e})$ & [17] & - \\
\hline NCR & $10^{3}-10^{6}(d, e, i)$ & {$[17]$} & & & $10^{2}-10^{6}(d, e, i)$ & {$[17]$} & - \\
\hline \multirow[t]{2}{*}{$\left.N M R\right|^{5}$} & & & $10^{4}(f)$ & {$[156,157]$} & $10^{4}-10^{12}$ & [158] & - \\
\hline & & & $10^{4}-10^{12}(f, g, h, i)$ & [158] & $(f, g, h, i)$ & & \\
\hline Swiss & & & $10^{5}(\mathrm{~b})$ & [159] & & & - \\
\hline \multirow[t]{2}{*}{ Swiss-Webster } & & & & & $10^{1}-10^{5}(\mathrm{i})$ & [115] & - \\
\hline & & & & & $10^{5}-10^{7}(\mathrm{c})$ & [155] & \\
\hline Swiss white & & & & & $10^{7}(\mathrm{a}, \mathrm{d}, \mathrm{e})$ & [18] & - \\
\hline Porton & $>10^{10}(b, d, e, i)$ & [160] & & & & & - \\
\hline $129 \mathrm{~Sv} \times \mathrm{C} 57 \mathrm{BL} / 6$ & & & & & $10^{4}(b)$ & [161] & intermediate \\
\hline iFABP-hEcad ${ }^{2}$ & $\sim 10^{10}(\mathrm{~b})$ & [149] & & & & & transgenic \\
\hline E16PmEcad ${ }^{6}$ & $\mathrm{n} / \mathrm{a}$ & & & & & & transgenic \\
\hline
\end{tabular}

Animals represent non-pregnant adults unless stated otherwise.

${ }^{1}$ body weights ranging from $10-20$ grams; ${ }^{2}(\mathrm{C} 57 \mathrm{BL} / 6 \mathrm{~J} \times \mathrm{SJL} / \mathrm{J})$ background; ${ }^{3}$ suckling mice; ${ }^{4}$ adult mice; ${ }^{5}$ derived from swiss-type mouse; ${ }^{6}$ only competitive indexing experiments performed; ${ }^{7}$ juvenile mice; ${ }^{8}$ geriatric mice

L. monocytogenes strains:

(a) L.monocytogenes Scott A (serotype 4b); (b) L.monocytogenes EGD (serotype 1/2a); (c) L. monocytogenes 10403S (serotype 1/2a); (d) human clinical isolate; (e) food isolate; $(\mathrm{f}) \mathrm{L}$. monocytogenes $4 \mathrm{~b}$ isolate; $(\mathrm{g}) \mathrm{L}$. monocytogenes $1 \mathrm{~b}$ isolate; $(\mathrm{h}) \mathrm{L}$. monocytogenes $3 \mathrm{a}$ isolate; (i) other or not specified $\mathrm{L}$. monocytogenes isolate. 
A variety of immunological, genetic and physiological determinants therefore impact susceptibility of mice to L. monocytogenes infection, and may complicate comparisons across studies.

\subsection{Pathogenicity differences among $L$. monocytogenes strains}

Regardless of the mouse strain or the host's physiological status, susceptibility of mice to intragastric as well as other routes of inoculation clearly depends on the L. monocytogenes strain used for inoculation (Table 1). For example, when mice of the BALB/c strain were inoculated through the intragastric route with $2 \times 10^{9}$ cfu of different L. monocytogenes strains, bacterial loads in internal organs clearly differed among L. monocytogenes strains [169].

L. monocytogenes strains are known to differ in their pathogenicity for humans, and the molecular determinants of these pathogenicity differences are beginning to be elucidated [55]. Notably, while a large fraction of strains isolated from food sources contain a premature stop codon in the inlA gene that attenuates their virulence, such attenuated strains are rarely isolated from human cases, and outbreak strains generally express full-length InlA [55]. Similar to these pathogenicity differences among humans, mice appear to be more susceptible to infection with human outbreak strains than with isolates from food sources. For example, systemic infection was significantly $(p<0.01)$ more likely in mice of strain A/J inoculated with $10^{6}$ CFU of epidemic L. monocytogenes strains from human outbreaks than in mice inoculated with similar amounts of L. monocytogenes strains from environmental or food sources [136]. Similarly, after challenging adult mice of the NCR strain with different L. monocytogenes isolates from clinical and food source, $\mathrm{LD}_{50}$ values ranged from $10^{3}$ to $10^{5} \mathrm{cfu}$ [17]. In outbred mice of the ICR strain, intragastric inoculation with $10^{6} \mathrm{cfu}$ of L. monocytogenes Scott A, a serotype 4b strain, led to pathologically more severe lesions than inoculation with equal amounts of $L$. monocytogenes strain EGD, a serotype $1 / 2$ a strain, again reflecting pathogenicity trends among humans [170]. Surprisingly, pretreating mice with sodium bicarbonate to neutralize the stomach $\mathrm{pH}$ appeared to have a considerably more pronounced effect on infections with strain EGD than on infections with the Scott A strain [170]. Similarly pronounced differences among $L$. monocytogenes subtypes have been observed in pregnant gnotobiotic $\mathrm{BALB} / \mathrm{c}$ mice after oral challenge, with a serotype 3 strain apparently unable to colonize the murine gut and invade the host [154]. Back-crossed (C57BL/6 $\times$ DBA/2) mice, inoculated intragastrically with $2 \times 10^{9}$ cfu of hemolytic or non-hemolytic L. monocytogenes strains showed considerably different bacterial loads in mesenteric lymph nodes, spleen and liver, again emphasizing the similarities in
L. monocytogenes strain specific pathogenicity between mice and humans [171]. Properties of the inoculum strain, in addition to immunological and physiological properties of the host, therefore seem to significantly impact the outcome of experimental L. monocytogenes inoculations in mice, and L. monocytogenes strain specific pathogenicity differences in mice may at least partially reflect pathogenicity differences in humans.

\section{Species-specific interactions between internalines and host cells}

Discovery of the InlA and InlB dependent mechanisms by which L. monocytogenes is thought to transgress the intestinal and placental barriers has resulted in a critical re-evaluation of mice and other traditional small animal models of listeriosis [24]. L. monocytogenes invasion proteins InlA and InlB are members of the internalin family, proteins with leucine-rich repeats (LRRs) [172]. Experimental inoculations in a variety of animal species, in primary cell lines, organ explants and immortalized cell lines using L. monocytogenes wild type, inlA, inlB and inlA/inlB deletion mutations and an inlA expressing $L$. innocua mutant have provided compelling evidence for the roles of these bacterial proteins in mediating internalization of L. monocytogenes into nonphagocytic cells [24]. The N-terminal regions of InlA and InlB contain signaling peptides and LRRs [172]. The C-terminal region of InlA contains a conserved LPXTG motif that confers covalent binding to peptidoglycans on the bacterial cell surface, while InlB contains a G-W motif, resulting in non-covalent binding to lipoteichoic acids in the bacterial cell wall $[172,173]$. Notably, due to the noncovalent nature of the binding InlB can be liberated from the bacterial cell wall, a process that is thought to play intricate roles during infection [174].

The importance of InlA for L. monocytogenes entry into non-phagocytic cells was demonstrated in 1991 when L. monocytogenes InlA was shown to confer L. innocua the ability to enter human Caco-2 cells (origin: human epithelial colorectal adenocarnicoma) and this finding has since been repeatedly confirmed [172,175,176]. Analogously, InlB has been shown to be required for L. monocytogenes internalization into various cell types such as immortalized Vero (origin: African green monkey kidney), HeLA (origin: human cervical adenocarcinoma), and $\mathrm{CHO}$ (origin: Chinese hamster ovary) cells $[173,177]$. An in vivo role of InlA and/or InlB, which are both encoded by the inlAB operon, for L. monocytogenes infection was suggested by Gaillard et al. in 1996, using a L. monocytogenes EGD $\Delta$ inlA/inlB deletion mutant [36]. After oral or intravenous challenge of SPF female Swiss mice with $10^{9}$ or $10^{5} \mathrm{cfu}$ of the L. monocytogenes EGD $\Delta$ inlA/inlB deletion mutant, Gaillard et al. detected bacterial concentrations in the liver that were considerably lower than after challenge with 
EGD wt, and estimated $\mathrm{LD}_{50}$ values after intraveneous challenge equaled $5 \times 10^{6}$ and $3.5 \times 10^{7}$ for EGD wt and EGD $\Delta$ inlA/inlB, respectively [36]. Gaillard et al. also showed a reduced ability of $L$. monocytogenes EGD $\Delta$ inlA/ inlB to invade TIB-73 cells, an immortalized hepatocyte line derived from BALB/c mice [36].

\subsection{Interactions between E-cadherin and InIA}

E-cadherin (Ecad, $\mathrm{Ca}^{2+}$ dependent selective hemophilic adhesion molecule) is a transmembrane adhesion protein that mediates cell-cell junctions on epithelial cells and plays essential roles during embryonic development $[172,174]$. Ecad is expressed on most epithelial cells, but seems to be frequently replaced by $\mathrm{P}$-cadherin on tumor cells, which may caution against the use of certain tumor-derived cell lines for the study of E-cadherin expression [178]. Ecad expression on polarized epithelial cells is typically located in adherence junctions and on the basolateral surface [172]. E-cadherin was identified as InlA receptor in 1996, again using human Caco-2 cells [179]. LCAM, a chicken ortholog of human Ecad, which shares approximately 65\% sequence homology with Ecad [180], has been shown to promote InlA dependent entry into transfected immortalized fibroblast cell lines S180 (origin: Swiss mouse sarcoma) and L2071 (origin: C3H/ An mouse connective tissue), providing convincing evidence that Ecad is sufficient to promote L. monocytogenes entry into these nonphagocytic cells $[177,179]$. The mechanism of InlA-mediated entry has since been elucidated: interactions between InlA and Ecad, located in lipid rafts, trigger intricate intracellular cascades that lead to actin rearrangement and ultimately result in caveolindependent endocytosis [11,172,174,181,182].

Murine Ecad (mEcad) has been cloned and studied extensively, primarily due to the crucial role of this molecule in cell sorting and cell-cell recognition during embryogenesis [180,183]. mEcad and human E-cadherin (hEcad) share approximately $85 \%$ sequence identity [180]. Surprisingly, however, L. innocua expressing InlA appeared unable to enter murine NMe cells (derived from NMuMG cells, an immortalized line of mouse mammary epithelial cells $[180,184])$, even though these cells have been shown to express high mEcad levels [180]. Similarly, transfection of various immortalized cell lines with mEcad (a cDNA construct originally derived from murine F9 embryonal carcinoma cells (i.e., an immortal cell line derived from $129 / \mathrm{Sv}$ inbred mice) for structure/function studies [180,185-187]) failed to promote entry of the L. innocua mutant expressing InlA, even though this L. innocua mutant readily entered the same cell lines transfected with human Ecad or chicken LCAM [180]. The inability of mEcad to promote InlA-dependent entry has been linked to a P16E mutation in the first extracellular domain of mEcad [180]. The sequence of rat Ecad at position 16 of this domain, also a glutamic acid, was determined using immortalized NBT2 (origin: rat bladder carcinoma) cells [180]. Guinea pigs, rabbits and gerbils, on the contrary, harbor a proline at position $16[12,180,188]$. This information was determined using GPC16 cells (origin: guinea pig colorectal adenocarcinoma), rabbit corneal epithelial cell cultures, and gerbil primary intestinal epithelial cell cultures $[12,180,188]$.

The inlA gene of L. monocytogenes strain EGD has been successfully "murinized", leading to considerably increased susceptibility of wild type mice to infection with the murinized L. monocytogenes strains [189,190]. Two point mutations (i.e., S192N and Y369S) located in the inlA gene of murinized L.monocytogenes strain EGD-InlA ${ }^{\mathrm{m}}$, have been shown to lead to increased susceptibility of C57BL/6 and $\mathrm{BALB} / \mathrm{c}$ mice to oral infection, resulting in an $\mathrm{LD}_{50}$ of approximately $5 \times 10^{7} \mathrm{CFU}$ in C57BL/6 mice, while only approximately $20 \%$ of C57BL/ 6 mice challenged with $5 \times$ $10^{10} \mathrm{cfu}$ of wild type EGD died $[189,190]$. An N259Y mutation in L. monocytogenes EGD inlA has also been shown to promote efficient infection of BALB/c mice after intra-gastric inoculation [190].

iFABP-hEcad transgenic mice, generated in a (C57BL/6 J $\times \mathrm{SJL} / \mathrm{J})$ background, express hEcad under control of the $i F A B O$ promoter [149]. In these mice, hEcad expression is limited to the intestine while mEcad is expressed on all epithelial cells that express mEcad in wild-type mice. iFABP-hEcad mice showed $85 \%$ mortality after oral challenge with $5 \times 10^{10} \mathrm{CFU}$ of L. monocytogenes strain EGD while $100 \%$ of wild-type mice of the same murine strain and challenged under identical conditions survived [149]. This translates into $\mathrm{LD}_{50}$ values of $>10^{10}$ and approx. $10^{10}$ for wild type and iFABP-hEcad mice, respectively (Table 1). Notably, $100 \%$ of wild type and transgenic mice challenged with the same dose of EGD $\Delta$ inlA, an inlA knock-out strain of L. monocytogenes EGD, survived [149]. These results are comparable to those obtained for guinea pigs challenged with $5 \times 10^{11} \mathrm{CFU}$ of EGD or EGD $\triangle i n l A$, respectively, with the $\mathrm{LD}_{50}$ for wt EGD in guinea pigs equaling approx. $10^{11} \mathrm{cfu}$ [149]. Like (starved) wild type mice, (starved) gnotobiotic Fabpi-hEcad mice, generated by back-crossing iFABP-hEcad transgenic mice to mice of strain C57BL/6 J and reared under gnotobiotic conditions, did not exhibit mortality after oral inoculation with $10^{9}$ cfu of EGD or EGD $\Delta i n l A$, even though some clinical symptoms were reported [191]. Notably, in gnotobiotic Fabpi-hEcad mice, EGD was detected in villus enterocytes and the underlying lamina propria while such observations were not made in wild type mice [191]. However, L. monocytogenes EGD $\triangle$ inlA strains were able to infect the spleen of gnotobiotic Fabpi-hEcad mice, albeit at levels below those observed in Fabpi-hEcad mice infected with EGD, strongly indicating the presence of alternate infection pathways in these mice [191]. 
E16PmEcad knock-in mice ${ }^{\mathrm{a}}$ carry a point mutation at position 16 of the first extracellular domain of murine E-cadherin that changes the glutamic acid at this position to a proline (i.e., E16P mutation) [12]. E16PmEcad mice are homozygous and therefore exclusively express "humanized" E-cadherin on all tissues where murine Ecadherin is expressed in wild-type mice [12]. In (starved) E16PmEcad mice experimental inoculation with $10^{9} \mathrm{cfu}$ EGD, InlA-dependent crossing of the intestinal barrier has been observed [12]. Unfortunately, information as to whether deaths were observed with this challenge dose was not provided and the available data do not permit calculation of $\mathrm{LD}_{50}$ values [12].

\subsection{InlB and its three receptors}

The hepatocyte growth factor receptor (HGFR or MET), complement component $1 \mathrm{Q}$ subcomponent-binding protein (gC1qR) and glycosaminoglycans are known receptors for InlB and have been shown to mediate L. monocytogenes entry into a broad variety of host cells [192-194]. gC1pR is a ubiquitous, multiligand binding glycoprotein and acts as receptor for complement $\mathrm{C} 1$ [172]. Specific interactions between gC1pR and InlB have been documented and gC1pR and MET appear to act synergistically [173]. MET, a receptor tyrosine kinase, is expressed on a wide variety of epithelial and endothelial cells and binds hepatocyte growth factor (HGF) with high affinity [192-194]. MET is important for normal embryonic development, but also appears to play a key role in oncogenesis [173]. InlB binding leads to MET activation through transient phosphorylation of its multiple docking sites [173]. A complex intracellular cascade (see for instance [173,174] for a review) subsequently leads to actin reorganization, manifested as "membrane roughing", and culminates in clathrin-mediated endocytosis $[173,174]$. MET activation through HGF binding is considerably enhanced by the presence of glucosaminoglycanes (GAG) on the cell surface [173]. Notably, the C-terminus of InlB has also been shown to bind GAGs on the host cell surface, and InlBdependent invasion is impeded in the absence of GAG $[173,194]$.

The importance of InlB for L. monocytogenes infection has been demonstrated in-vivo and in-vitro. Bacterial counts in the liver and spleen of BALB/c mice, intravenously inoculated with $3 \times 10^{3} \mathrm{cfu}$ of EGD $\Delta$ inlB, were significantly $(p<0.02)$ lower $72 \mathrm{~h}$ after inoculation than in mice inoculated with the same dose of EGD wt, strongly suggesting a role of InlB-dependent colonization of these organs during L. monocytogenes infection in mice [45]. Surprisingly, however, such InlB dependence was neither observed in (starved) guinea pigs inoculated intragastrically with $10^{10} \mathrm{cfu}$ (plus calcium carbonate) or intravenously with $10^{6} \mathrm{cfu}$ of the same $L$. monocytogenes strains, nor in rabbits inoculated intravenously with $10^{6}-10^{7} \mathrm{cfu}$ of the same strains [45]. Species-specific differences in internalization efficacy were confirmed in-vitro using immortalized cell lines of human, mouse, rabbit, and guinea pig origin $^{\mathrm{b}}$ [45]. Nearly all tested cell lines from guinea pigs and rabbits expressed both MET and gC1qR [45]. However, in guinea pig derived cell lines neither InlB nor human HGF induced membrane ruffling, a prerequisite for InlB dependent internalization [45]. In rabbit-derived cells, the presence of human HGF, but not InlB, induced such membrane ruffling [45]. Surprisingly, transfection of human MET conferred permissiveness in guinea pig and rabbit cell lines, indicating likely species-specific receptor differences [45]. In gerbils, both InlA and InlB mediated entry pathways appear to be functional as determined using primary intestinal cell cultures and confirmed in vivo using pregnant gerbils, but calculation of $\mathrm{LD}_{50}$ values has so far unfortunately not been possible [12]. Gerbils may conceivably represent an attractive rodent model of L. monocytogenes infection [12]. As perhaps expected for a rodent species, gerbils appear to cluster with mice and rats in dendograms based on either the Ecad or the MET sequence, but may form a separate phylogenetic clade in the Ecad phylogeny [12].

Other, currently unknown species-specific differences may exert so far unrecognized impacts on L. monocytogenes infections. Various $L$. monocytogenes virulence proteins such as listeriolysin $\mathrm{O}$ or ActA have been shown to play crucial roles in the L. monocytogenes infection pathway, while the role of other proteins is just beginning to be recognized [24]. Vip, for instance, encodes another L. monocytogenes LPXTG surface protein, which interacts with endoplasmatic reticulum resident chaperon Gp96 [195]. Guinea pigs as well as iFABP-hEcad transgenic mice have been shown to harbor lower bacterial loads in the liver, intestine, lymph nodes and spleen when orally inoculated with $10^{10} \mathrm{cfu}$ or $5 \times 10^{9} \mathrm{cfu}$, respectively, of L. monocytogenes EGD $\Delta$ vip than when inoculated with the same doses of wt EGD, and similar observations have been made in BALB/c mice after intravenous inoculation [195]. Potential differences in vip-Gp96 interactions in other animal species, however, remain yet-to-be determined. As the interactions between $L$. monocytogenes and its host are increasingly being understood, new criteria for the adequacy of animal models of human listeriosis will likely continue to emerge.

\section{Other animal models of non-pregnancy- associated listeriosis}

The mouse model has been the most commonly used animal model of L. monocytogenes infection due to its size, ease of handling, and relatively low economic cost $[11,23]$. Moreover, the commercial availability of many reagents for immunological studies, the extensive available data on mouse physiology, anatomy, embryogenesis 
and immunology, and the existence of well-characterized inbred mouse strains with known physiological and immunological characteristics have contributed to the immense popularity of the non-pregnant mouse model of listeriosis. However, as discussed below, other small animal species have also occasionally been used to study certain aspects of $L$. monocytogenes infection and immunity in non-pregnant animals (Table 2). Since the species-specific differences in InlA-Ecad and InlB-MET interactions have been discovered, the value of mice, as well as rats, guinea pigs and rabbits as models for listeriosis in humans has been questioned [11]. Non-human primates or unconventional small-animal models, such as gerbils, may ultimately prove to be superior models of listeriosis, but only limited data on $L$. monocytogenes infections and immune responses in these animal species are so far available and ethical, economic and practical considerations, especially for non-human primates, will necessarily limit the number and size of studies that can be performed in these animal species.

\subsection{Non-pregnant rat models}

Non-pregnant rats have been used repeatedly as models of L. monocytogenes infection, and rat antibodies have been used in mice to study the immunology of listeriosis [25,33,196-203]. Formal $\mathrm{LD}_{50}$ values after oral inoculation of adult rats are not available in the literature, but rats appear to be relatively resistant to infection. For example, juvenile rats orally inoculated with $10^{2}-10^{9}$ cfu of a L. monocytogenes $4 \mathrm{~b}$ strain developed dose-dependent invasive infection as measured by the presence of culturable bacteria in internal organs, but did not exhibit clear clinical symptoms or death [128,197]. Notably, treatment with cimetidine, a histamine receptor agonist that inhibits acid production in the stomach, significantly $(p<0.05)$ increased the probability of invasive infection in rats inoculated with less than $10^{9} \mathrm{cfu}$, but did not significantly $(p>0.05)$ affect bacterial counts in the liver or spleen of infected animals, and bacterial counts in the organs did not appear to be dose dependent $(p>0.05)$ [197]. $\mathrm{LD}_{50}$ values for infant rats inoculated 3 days post-partum and juvenile rats, inoculated 13 days post-partum, determined after subcutaneous injection of an L. monocytogenes serotype $4 \mathrm{~b}$ strain, equaled $6 \times 10^{5}$ and $2.5 \times 10^{7}$, confirming the relatively high infectious dose for rats [204]. Rats have also for instance been used to study the impact of the gut microflora on susceptibility to infection [202]. In these experiments the presence of a normal gut microflora appeared to be somewhat protective of $L$. monocytogenes infection [202]. Gnotobiotic rats orally inoculated with $2 \times$ $10^{9} \mathrm{cfu}$ of a L. monocytogenes serotype 1 strain exhibited weight loss, splenomegaly and histopathological lesions, and bacteria were readily recovered from the spleen and liver, even though rats appeared clinically healthy [202]. In conventionally reared rats or gnotobiotic rats switched to conventional feed during the experiment, however, L. monocytogenes appeared to be efficiently cleared from internal organs [202]. Rat ligated intestinal loop systems have been used to study early intestinal steps of L. monocytogenes infection - even though the Ecad receptor differences discussed above have since raised concern about the relevance of this system for modeling human infection $[11,25,33]$. Analogous to mice, rat models of L. monocytogenes infection have been used to study immune responses to infection [201]. Young rats have also been used to establish rat models of meningitis, and to evaluate the impact of different therapeutic regimens in these models [200]. For instance, in one of these experiments, rats were inoculated by intracisternal injection of $5 \times 10^{4}-1 \times 10^{5}$ cfu of an L. monocytogenes $4 \mathrm{~b}$ strain and developed depression, weight loss and meningitis within one day of inoculation [200].

\subsection{Non-pregnant guinea pig models}

Non-pregnant guinea pigs have been used as models for listeriosis, even though inoculations have also often been performed in pregnant guinea pigs [16,53,205-208]. Guinea pigs appear to be somewhat more resistant to infection than most strains of mice, irrespective of the inoculation route [23]. High numbers of bacteria appear to be required to install infection in non-pregnant guinea pigs. $\mathrm{LD}_{50}$ values of about $10^{11} \mathrm{cfu}$ and greater than $10^{8}$ cfu have been reported for oral and intraperitoneal inoculation, respectively $[149,205]$, and for this reason, a standard dose of $10^{10} \mathrm{cfu}$ of $L$. monocytogenes EGD has been suggested for oral inoculation of guinea pigs, compared to doses of $10^{8}-5 \times 10^{9} \mathrm{cfu}$ for mice [209]. Guinea pigs appear most susceptible to inoculation through the intracardial route, with an $\mathrm{LD}_{50}$ value of $1.2 \times 10^{5} \mathrm{cfu}$, while intravenous and intraperitoneal $\mathrm{LD}_{50}$ values appear to be high, in the range of $10^{7}-10^{8} \mathrm{cfu}$ and $>2.5 \times 10^{8}$, respectively [205].

Other infection endpoints than death have occasionally been used in guinea pig studies and guinea pigs have for instance been used to identify differences in infectious doses among L. monocytogenes strains after oral inoculation [210]. Infectious doses of $10^{7}-10^{8} \mathrm{cfu}$ after oral inoculation of juvenile male guinea pigs with an L. monocytogenes strain carrying a point mutation in inlA, and approximately $1 \log$ lower infectious doses for inoculations with outbreak strains without the inlA mutation, have been reported [210]. Other researchers have also reported the ability to reproduce differences in L. monocytogenes pathogenicity among strains using orally infected non-pregnant guinea pigs [211]. However, infectivity again appeared to be relatively low. Rolgaard et al., for instance, gave two doses of $2 \times 10^{10} \mathrm{cfu}$ each to the animals, one day apart [211]. He noted no deaths 
Table 2 Summary of benefits and limitations of the different animal models (see text for details and references)

\begin{tabular}{|c|c|c|c|c|c|c|}
\hline \multirow[b]{2}{*}{ Species } & \multicolumn{3}{|c|}{ Non-pregnant animals } & \multicolumn{3}{|c|}{ Pregnant animals } \\
\hline & Popularity & Benefits & Limitations & Popularity & Benefits & Limitations \\
\hline mouse & high & & & $\begin{array}{l}\text { moderate/ } \\
\text { high }\end{array}$ & $\begin{array}{l}\text { - same as for non- } \\
\text { pregnant animals } \\
\text { - similarities to } \\
\text { human } \\
\text { - placentation well } \\
\text { characterized }\end{array}$ & $\begin{array}{l}\text { - mutation in receptor for InIA } \\
\text { (Ecad)affects crossing of } \\
\text { placental barrier } \\
\text { - small body size }\end{array}$ \\
\hline rat & moderate & $\begin{array}{l}\text { - well characterized } \\
\text { - economical } \\
\text { - large sample size } \\
\text { possible } \\
\text { - inbred strains } \\
\text { available } \\
\text { - immune reagents } \\
\text { available } \\
\text { - body size optimal } \\
\text { for certain } \\
\text { manipulations } \\
\text { - proven ability to } \\
\text { model bacterial strain } \\
\text { variability }\end{array}$ & $\begin{array}{l}\text { - mutation in receptor for InIA } \\
\text { (Ecad)affects entry into } \\
\text { enterocytes } \\
\text { - quite resistant to infection }\end{array}$ & moderate & $\begin{array}{l}\text { - same as for non- } \\
\text { pregnant animals } \\
\text { - similarities to } \\
\text { human } \\
\text { placentation } \\
\text { - body size optimal } \\
\text { for certain } \\
\text { manipulations }\end{array}$ & $\begin{array}{l}\text { - mutation in receptor for InIA } \\
\text { (Ecad) affects crossing of } \\
\text { placental barrier } \\
\text { - quite resistant to infection }\end{array}$ \\
\hline rabbit & $\begin{array}{l}\text { moderate/ } \\
\text { low }\end{array}$ & $\begin{array}{l}\text { - well characterized } \\
\text { - economical } \\
\text { - large sample size } \\
\text { possible } \\
\text { - commonly used to } \\
\text { generate antibodies } \\
\text { - quite susceptible to } \\
\text { infection }\end{array}$ & $\begin{array}{l}\text { - InIB receptor (MET) } \\
\text { polymorphism affects entry into } \\
\text { cells such as hepatocytes }\end{array}$ & $\begin{array}{l}\text { moderate/ } \\
\text { low }\end{array}$ & $\begin{array}{l}\text { - same as for non- } \\
\text { pregnant animals } \\
\text { - similarities to } \\
\text { human } \\
\text { placentation } \\
\text { - body size } \\
\text { optimal for certain } \\
\text { manipulations }\end{array}$ & $\begin{array}{l}\text { - mutation in InIB receptor } \\
\text { (MET) affects crossing of } \\
\text { placental barrier }\end{array}$ \\
\hline $\begin{array}{l}\text { guinea } \\
\text { pig }\end{array}$ & moderate & $\begin{array}{l}\text { - well characterized } \\
\text { - economical } \\
\text { - large sample size } \\
\text { possible } \\
\text { - body size optimal } \\
\text { for certain } \\
\text { manipulations } \\
\text { - ability to model } \\
\text { bacterial strain } \\
\text { variability }\end{array}$ & $\begin{array}{l}\text { - InIB receptor (MET) } \\
\text { polymorphism affects entry into } \\
\text { cells such as hepatocytes } \\
\text { - quite resistant to infection } \\
\text { - pathological lesions often } \\
\text { limited to myocardium }\end{array}$ & high & $\begin{array}{l}\text { - same as for non- } \\
\text { pregnant animals } \\
\text { - similarities to } \\
\text { human } \\
\text { placentation } \\
\text { - body size optimal } \\
\text { for certain } \\
\text { manipulations }\end{array}$ & $\begin{array}{l}\text { - mutation in InIB receptor } \\
\text { (MET) affects crossing of } \\
\text { placental barrier } \\
\text { - quite resistant to infection }\end{array}$ \\
\hline gerbil & increasing & $\begin{array}{l}\text { - quite susceptible to } \\
\text { infection } \\
\text { - functional receptors } \\
\text { for InIA (Ecad) and } \\
\text { InIB (MET) }\end{array}$ & $\begin{array}{l}\text { - not very well characterized } \\
\text { - no immune reagents } \\
\text { - small body size less economical }\end{array}$ & increasing & $\begin{array}{l}\text { - same as for non- } \\
\text { pregnant animals }\end{array}$ & $\begin{array}{l}\text { - same as for non-pregnant } \\
\text { animals }\end{array}$ \\
\hline chinchilla & low & - highly susceptible & $\begin{array}{l}\text { - not well characterized } \\
\text { - inlA \&inlB receptor sequences } \\
\text { unknown } \\
\text { - no immune reagents less } \\
\text { - economical }\end{array}$ & low & $\begin{array}{l}\text { - same as for non- } \\
\text { pregnant animals }\end{array}$ & $\begin{array}{l}\text { - same as for non-pregnant } \\
\text { animals }\end{array}$ \\
\hline hamster & low & - economical & $\begin{array}{l}\text { - resistant to infection } \\
\text { - inlA } \& \text { in/B receptor sequences } \\
\text { unknown small body size }\end{array}$ & low & $\begin{array}{l}\text { - same as for non- } \\
\text { pregnant animals }\end{array}$ & $\begin{array}{l}\text { - same as for non-pregnant } \\
\text { animals }\end{array}$ \\
\hline primate & moderate & $\begin{array}{l}\text { - close phylogenetic } \\
\text { relationship to } \\
\text { humans }\end{array}$ & $\begin{array}{l}\text { - ethical and economic } \\
\text { considerations } \\
\text { - limited sample size } \\
\text { - no immune reagents }\end{array}$ & moderate & $\begin{array}{l}\text { - same as for non- } \\
\text { pregnant animals }\end{array}$ & $\begin{array}{l}\text { - same as for non-pregnant } \\
\text { animals }\end{array}$ \\
\hline
\end{tabular}

in response to these inoculations, and the occurrence of clinical symptoms such as depression and ruffed coat in only a few of the animals, on the day of euthanasia, even though bacteria could be harbored from the organs of most animals [211]. Oral inoculations of (starved) guinea pigs in the presence of calcium carbonate with $10^{10}$ cfu of different L. monocytogenes strains led to reduced weight gain but did not cause noticeable clinical symptoms, perhaps again indicating a comparably low susceptibility to infection, even though the observation 
of clinical symptoms is dependent on the time of followup after inoculation [212]. Similar observations were also made in a study to evaluate the potential impact of food matrix on infectivity [213]. Pang and Matthews did not detect any clinical symptoms in starved, orally challenged guinea pigs, even if infectious doses of $10^{8} \mathrm{cfu}$ of a $L$. monocytogenes serotype $4 \mathrm{~b}$ strain were used, and differences in bacterial loads in internal organs between food matrices were also not detected [213]. Geriatric guinea pig models have been used to evaluate the impact of immune modulation in elderly animals [21]. However, intragastric inoculation with $2.5 \times 10^{8} \mathrm{cfu}$ of a $L$. monocytogenes serotype $4 \mathrm{~b}$ strain again failed to produce death in the geriatric guinea pigs, and the presence of clinical symptoms was not described [21].

\subsection{Non-pregnant rabbits as models of listeriosis}

Rabbits appear relatively susceptible to infection with L. monocytogenes, even though $\mathrm{LD}_{50}$ values have not been formally calculated [23]. Rabbits have typically been used to generate anti-Listeria monocytogenes antibodies and to study immune responses to L. monocytogenes infection [214-216]. However, rabbits have occasionally also been used to model other aspects of $L$. monocytogenes infection, for instance to evaluate therapies for listeric meningitis [217]. Scheld et al., for example, inoculated animals with relatively high doses of $10^{7}$ cfu of a L. monocytogenes strain from a human meningitis case by injection into the cisterna, and used changes in bacterial concentrations in the spinal fluid to evaluate the efficacy of different chemotherapies [217]. Abscess formation after subcutaneous inoculation of rabbits has also been reported [23].

\subsection{Other non-pregnant rodent models}

Nontraditional rodent species such as gerbils, chinchillas and lemmings, have occasionally been used as models of L. monocytogenes infection [23]. Chinchillas appear to be highly susceptible to oral inoculation, but seem to have been rarely used due to economic and practical considerations [23]. Chinchillas and gerbils have been used successfully to model listeric rhombencephalitis in animals with prolonged otitis media and bacteremia [218]. Gerbils were inoculated with $10^{3}$ or $10^{5}$ cfu of L. monocytogenes EGD by percutaneous injection into the superior chamber of the middle ear bulla [218]. Animals inoculated with high doses succumbed to disease 4-7 days after inoculation, while animals inoculated with low doses survived for 6-12 days [218]. Most gerbils exhibited behavioral changes, and typical neurological symptoms such as circling, ataxia, and paresia were observed at relatively late stages during infection [218]. Gerbils have also recently been used to model oral inoculation, even though only a relatively small number of animals were used and inoculation of $10^{9} \mathrm{cfu}$ of L. monocytogenes EGD did not appear to cause severe clinical symptoms in these animals [12]. Hamsters have rarely been used as models of listeriosis, but have been reported to be comparably resistant to infection [23]. Voles, on the contrary appear to be fairly susceptible to intra-peritoneal infection, but have rarely been used due to practical constraints on availability [23].

\subsection{Non-human primates as models of listeriosis}

Only a small number of experimental studies in nonhuman primates have been reported, primarily in pregnant animals $[13,14]$. However, Farber et al. inoculated nonpregnant cynomolgus monkeys with between $10^{5}$ and $10^{9}$ cfu of $L$. monocytogenes Scott A or a L. monocytogenes serotype $4 \mathrm{~b}$ isolate from a food source, suspended in sterile milk, and only detected mild clinical symptoms such as fever, irritability, inappetence and in some cases diarrhea, primarily in animals challenged with high doses [15]. Interestingly, no marked differences between the two L. monocytogenes strains and no impact of treatment with antacids were observed [15]. One ape was challenged twice, approximately 8 weeks apart, with $10^{9} \mathrm{cfu}$ of L. monocytogenes Scott A, and fecal shedding in this animal after the second inoculation appeared shorter than in monkeys dosed once, potentially indicating some protective effect of prior exposure [15]. A small number of other experimental inoculations of non-human primates have also been reported, establishing for instance that apes appear to be relatively resistant to ocular or aerosol inoculation, even though transient ocular symptoms or febrile infection, respectively, could be invoked in these animals $[23,115]$.

\section{Animal models of pregnancy-associated listeriosis}

Pregnancy significantly increases susceptibility to L. monocytogenes infection, regardless of the animal species or route of inoculation [23]. Similar to observations in non-pregnant animals, mouse strain specific differences in susceptibility of pregnant mice to $L$. monocytogenes infection have been reported, especially upon challenge with high doses [219]. Resistant mice strains exhibit a decreased risk of fetal resorption, lower mortality, and reduced bacterial loads in the liver and spleen as compared to susceptible mice strains [219]. The biological determinants of these differences, however, are currently still largely unclear.

The immunological, anatomical and physiological determinants of the increase in $L$. monocytogenes susceptibility during pregnancy have been subject to intense study, but have so far still only partially been resolved. Pregnancy is associated with immunological changes that result in a shift in the Th1/Th2 cytokine balance to favor Th-2 mediated, humoral responses [219]. Th-1 mediated cellular immune responses, primarily mediated through 
interferon gamma (INF $\gamma$ ) and tumor necrosis factor alpha (TNF $\alpha$ ), are crucial for successful control of infections with intracellular pathogens such as L. monocytogenes, but appear significantly down-regulated during pregnancy [219]. Mouse models have been used extensively to study immunological changes during pregnancy, encompassing both physiological changes needed to protect the fetus and responses elicited following infection. As shown in comparative studies of pregnant and nonpregnant female mice of the BALB/c strain, $\mathrm{T}$-cell mediated immune responses are significantly impaired during pregnancy and systemic INF $\gamma$ levels are downregulated while IL-10 levels are upregulated [219]. Following $L$. monocytogenes infection, increased systemic levels of TNF $\alpha$ and IL- 6 were detected in pregnant BALB/c mice compared to non-pregnant female BALB/c mice, while IL- 8 ortholog Chemokine (C-X-C motif) ligand 1 (CXCL1, previously called KC) appeared downregulated, indicating a likely role in the diminished ability to control L. monocytogenes infection [219]. Mouse models have also been instrumental in elucidating pregnancy-associated immunological changes in specific tissues. In the liver of pregnant mice of the BALB/c strain, for instance, transcription of TNF $\alpha$, INF $\gamma$ and inducible Nitric oxide synthase (iNOS) is decreased after experimental inoculation with L. monocytogenes as compared to non-pregnant female mice [219]. The ability of the immune system to control L. monocytogenes replication in the liver, spleen and other organs therefore appears to be severely hampered during pregnancy.

The intricate immunological and physical roles played by the placenta in shielding the fetus from infection are slowly being revealed [219]. The murine placenta appears to represent a transient component of the innate immune system [220]. Comparative studies in knock-out mice identified a crucial role of colony stimulating factor 1 (CSF-1) in the control of L. monocytogenes infection [220]. After experimental inoculation with $1 \times 10^{4} \mathrm{cfu}$ of L. monocytogenes EGD, CSF-1 induced expression of KC and macrophage inflammatory protein 2 (MIP-2) in the trophoblast resulted in recruitment of neutrophils, the predominant immune cells in the pregnant placenta [220]. Notably, wild type mice were able to control the infection by day 3 post inoculation, and carried their litters to term, while all knock-out mice aborted [220]. The placenta likely also encompasses other components of the innate immune system. For example, Toll-like receptors (TRLs) 2 and 4, components of the innate immune system that recognize the surface protein LPS present on the surface of grampositive bacteria, are expressed on human placentas and a role in host defense against $L$. monocytogenes during pregnancy appears likely $[221,222]$.

The placenta may represent an important $L$. monocytogenes harborage site during pregnancy, and may play a direct role in mediating increased susceptibility to infection. For example, inoculation of female non-pregnant and pregnant mice of strain CD1 through the intragastric route with $3 \times 10^{7} \mathrm{cfu}$ L. monocytogenes 10403S (serotype $1 / 2 \mathrm{a}$ ) or a serotype 4 non b strain resulted in (extrapolated) $\mathrm{LD}_{50}$ values of approx. $1.5 \times 10^{8} \mathrm{cfu}$ in pregnant animals [223]. None of the non-pregnant animals inoculated with $10^{8}$ cfu died [223]. Surprisingly, bacterial loads in the colon, spleen and liver after oral inoculation differed between the $L$. monocytogenes strains, but in general no significant $(p>0.05)$ difference in bacterial loads among pregnant and non-pregnant animals were observed [223]. However, embryo, yolk sack and decidual tissue frequently harbored high number of bacteria, and infection of decidual tissues appeared to be correlated with increased maternal mortality [223].

Many details about the mechanisms by which L. monocytogenes crosses the placental barrier and causes abortion or stillbirth remain yet to be fully understood. Abortion is a common outcome of listeriosis in humans, monogastric mammals as well as ruminants, regardless of the type of placentation $[23,55]$. Ruminants, pigs and horses have an epitheliochorial placenta. The placenta of carnivores is an endotheliochorial placenta. Primates, rodents and lagomorpha, on the contrary, share a hemochorial placenta, characterized by direct contact between fetal chorion and maternal capillaries. Importantly, fewer cellular layers between fetal chorion and maternal capillaries generally result in more efficient transfer of nutrients and other macromolecules including immunoglobulins. The placentas of humans and mice are both of discoidal type and have been studied and compared extensively, primarily to study physiological and pathological processes during human pregnancy. Especially during the third trimester of gestation, human and murine placentas share considerable similarities in structure, function and likely also in the embryonic origin of placental cells [224]. However, some anatomical differences between the two species exist. For instance, in the murine placenta the spaces that contain the maternal capillaries appear considerably more mazelike than in human placentas while the fetal capillaries have a porous instead of continuous endothelium that facilitates exchange of small molecules (see [224] for a detailed comparison). Proteomic and transcriptomic comparison of microdissected human and murine placentas, focusing on the regions of materno-fetal exchange (i.e., villous tree in humans and labyrinth in mice), revealed 7000 orthologous genes of which $70 \%$ were co-expressed in both mice and humans [225].

In the placentas of women with listeriosis, as well as in the placentas of naturally or experimentally inoculated animals, $L$. monocytogenes can be detected in the intervillous spaces, the villous core, and the trophoblast [23,24]. These observations, paired with the absence of bacteria 
from the connective tissue of the chorion in human placentas, led to the hypothesis that $L$. monocytogenes infection occurs through the transplacental route [24]. L. monocytogenes is thought to cross the placental barrier at the interface of syncytiotrophoblast and fetal blood vessel [12]. On the contrary to observations in mice and guinea pigs, crossing of the human placenta appears to be both InlA and InlB dependent [12]. In vivo experiments in pregnant gerbils demonstrated that intravenous infection with $2 \times 10^{6} \mathrm{cfu} L$. monocytogenes EGD consistently led to fetal infection, while EGD $i n l A$, inlB and $i n l A / B$ deletion mutants all showed significantly $(p<0.05)$ reduced placental invasion and fetal infection based on competitive indexing [12]. However, competitive indexing results appeared to vary somewhat among the deletion mutants and all deletion mutants appeared able to invade placenta and fetus, likely signifying the presence of alternate infection routes [12]. Surprisingly, in wild type mice and guinea pigs, invasion of the placenta appears to be neither InlA nor InlB dependent, but the placenta of E16PmEcad knock-in mice that express humanized Ecad in all organs, appears more than one order of magnitude more permissive to L. monocytogenes EGD than to the deletion mutants [12]. The exact mechanisms by which InlA and InlB dependent entry pathways interact in the placenta are currently unclear. Notably, cell-to-cell spread has also been shown to play a key role in fetal infection, at least in guinea pigs [53]. A variety of different infection pathways therefore appear capable of potentially leading to fetal infection, and species-specific differences likely impact fetal infections in different species.

Studies in pregnant animals differ considerably in the timing of inoculation relative to gestation, the length of follow-up after inoculation, and the study endpoint. Nonhuman primates and guinea pigs have received increasing attention in recent years, even though the adequacy of the guinea pig model has been critically re-evaluated since the species-specificity of the InlB-MET interactions have been elucidated [11,12]. Gerbils may represent promising rodent models of pregnancy-associated listeriosis, but the data available for this species are currently limited.

\subsection{Non-human primates as models of pregnancy- associated listeriosis}

A non-human primate model of $L$. monocytogenes induced stillbirth has been developed [14]. This animal model may potentially be the most appropriate model for human disease due to the close phylogenetic relatedness between humans and apes, but ethical, economic and practical considerations have thus far limited the number of studies and replicates available as well as the sample size. Stillbirth, premature birth as well as normal birth were observed in rhesus monkeys inoculated orally during the last trimester of gestation with $10^{2}-10^{10} \mathrm{cfu}$ of L. monocytogenes strain
Scott A, with another serotype $1 / 2$ a strain, or with 4 b strains $[13,14]$. The inoculum was delivered in whipping cream (i.e., 30\% milk fat), "half-and-half" (i.e., 11\% milk fat) or skim milk (i.e., < $1 \%$ milk fat) - with the latter two food vehicles abandoned after initial testing because infectivity appeared to be the highest in whipping cream $[13,14]$. The respective dose required to induce stillbirth in $50 \%$ of non-human primates has been estimated to fall in the range of $10^{6}-10^{8} \mathrm{cfu}$ L. monocytogenes, averaged across strains, gestation days and using whipping cream as food vehicle [13]. Clinical symptoms were not reported in any of the inoculated pregnant monkeys and L. monocytogenes was not isolated from all aborted fetuses $[13,14]$.

\subsection{Guinea pigs as models of pregnancy- associated listeriosis}

Pregnant guinea pigs have repeatedly been used to model listeriosis, using a variety of different endpoints of infection [53,206,208]. Similar to observations in non-pregnant guinea pigs, pregnant guinea pigs appear to be relatively resistant to L. monocytogenes. For instance, pregnant guinea pigs inoculated with up to $10^{8} \mathrm{cfu}$ of a L. monocytogenes serotype $1 / 2$ a strain through the oral route were not reported to exhibit clinical symptoms, even though 20 of the 22 dams inoculated with $10^{6}$ or more cfu harbored L. monocytogenes in the liver and spleen [16]. Noticeably, the occurrence of stillbirths appeared to be dose-dependent [226]. On average, 11\% (1/9), 30\% (3/10) and 75\% $(3 / 4)$ of the 23 dams inoculated with doses of $10^{6}, 10^{7}$ and $10^{8} \mathrm{cfu}$ aborted, and the average time interval between inoculation and abortion decreased from 20 to 10 days as the inoculation dose increased [227]. The occurrence of apoptosis in the placentas of these guinea pigs also appears to be dose-dependent [208]. The dose required to cause stillbirth in $50 \%$ of guinea pigs has been approximated at $10^{7} \mathrm{cfu}$ using an L. monocytogenes serotype $1 / 2$ a strain delivered orally in commercial heavy whipping cream [16]. Noticeably, mortality of fetuses in a given litter ranged from 0 to $95 \%$ and appeared to be dose-dependent [16]. Surprisingly, however, the level of bacterial invasion in the maternal liver did not appear to be a reliable predictor of fetal mortality [16].

Relatively high infectious doses seem to be needed to cause fetoplacental infection in guinea pigs [206]. Bakardjiev et al., for instance, reported that $10^{6} \mathrm{cfu}$ of L. monocytogenes strain $1043 \mathrm{~S}$ had to be given intravenously to cause maternal and fetoplacental infection [206]. When guinea pigs were inoculated with $2 \times 10^{7}$ $\mathrm{cfu}, \mathrm{L}$. monocytogenes appeared to accumulate in the placenta and placentas contained multifocal inflammatory lesions in the labyrinth as well as surrounding the maternal blood vessels [206]. Most, but not all fetuses of a given dam became infected during challenge with high doses [206]. In another study, pregnant guinea pigs 
(gestation day 42-52, representing $2^{\text {nd }}$ to $3^{\text {rd }}$ trimester of gestation in humans) were inoculated intravenously with $10^{9} \mathrm{cfu}$ L. monocytogenes $1043 \mathrm{~S}$ and L. monocytogenes was detected in the livers of all fetuses $24 \mathrm{~h}$ post inoculation [53]. Clinical symptoms in the pregnant guinea pigs, however, were not reported [53]. Notably, L. monocytogenes strain - specific differences in the ability to invade maternal, placental and fetal tissues of experimentally inoculated guinea pigs after oral inoculation in whipping cream have been described, indicating the likely importance of L. monocytogenes strain-specific properties for infection in pregnant as well as non-pregnant animals [228].

\subsection{Other rodent models of pregnancy- associated listeriosis}

As discussed above and similar to the use of geriatric mouse models to understand immunological responses [20], mice have repeatedly been used to understand immune responses to L. monocytogenes infection during pregnancy (see for instance $[229,230]$ ). Pregnant BALB/c mice, challenged through the intraperitoneal route with $10^{5} \mathrm{cfu}$ L. monocytogenes EGD, have also been used to demonstrate a protective role of $\mathrm{CpG}$ oligodeoxynucleotides (CpG ODN), short single-stranded synthetic DNA molecules that contain $\mathrm{CpG}$ motives which stimulate innate immune responses through TLR-9, on L. monocytogenes infection [231]. Pregnant mice appear to be considerably more susceptible to infection after oral inoculation than non-pregnant mice, but susceptibility in pregnant mice also differs with L. monocytogenes strain [223]. Comparison of different mice strains, gestation days at inoculation, and days of sacrifice identified $\mathrm{BABL} / \mathrm{c}$ mice as the most adequate strain and inoculation on gestation day 14 as the optimal timing [219]. Non-pregnant BALB/c mice appeared to clear bacteria more rapidly after intravenous inoculation with $2.5 \times 10^{4} \mathrm{cfu}$ of $L$. monocytogenes EGD than pregnant mice inoculated on varying days of gestation, with mean durations of infection equaling 7 and 14 days, respectively [232]. Clinical symptoms in the inoculated dams were not reported [232].

Increased susceptibility during pregnancy has also been demonstrated in rats after subcutaneous infection with a L. monocytogenes serotype $4 \mathrm{~b}$ strain, with $\mathrm{LD}_{50}$ values equaling $10^{8}$ and $10^{9} \mathrm{cfu}$ for pregnant and non-pregnant rats, respectively [204]. Susceptibility appeared to be the greatest on day 16 of gestation, while infection on gestation day 9 appeared to result in resorption of fetuses but survival of the dams [204]. Gerbils have recently been used as experimental models of infection and the data appears somewhat promising, but so far the data available on L. monocytogenes infection in this species is very scarce [12]. Ultimately, it appears that the final verdict regarding the most adequate model of L. monocytogenes infection during pregnancy has to be postponed until the pathophysiology and immunology of L. monocytogenes infection during pregnancy has been elucidated in sufficient detail to permit comprehensive evaluation of the strengths and limitations of different animal models. It seems for instance that the intricate and interdependent roles of InlA and InlB in the transgression of the placental barrier have to be understood completely and that the nature of alternate infection routes that appear to permit infection in vivo has to be elucidated before a final, evidence-based decision about the choice of animal models can be made.

\section{Geriatric models of listeriosis}

Elderly and immunosuppressed individuals are at a particularly high risk of acquiring listeriosis [55]. Animal models specific to these population subgroups have been developed and geriatric models have occasionally been used to study infections with L. monocytogenes, as well as other pathogens such as Salmonella, Staphylococcus aureus or Toxoplasma gondii [233-239] but such models are very cost intensive and numerous questions about their relevance for human disease remain [240]. In geriatric patients as well as in aged laboratory animals, aging and underlying diseases are often intricately linked [241]. Old laboratory mice, for instance, are very commonly affected by underlying conditions such as hepathopathies, glomerulonephropathies, or neoplasies, and age-dependent changes in cells, tissues and organs often begin to develop before mice reach their median life expectancy [240]. Animal species differ in median life expectancy, in common geriatric diseases and conditions, and for mice the aging process appears to differ considerably among strains [240,241]. The determination of age equivalencies between humans and laboratory rodents is complicated by dynamically changing age relationships over the course of life, with one study quoting age equivalencies for 12, 45 and 70 year old humans as 1, 13 and 24 month old mice [241]. Clear definitions of geriatric models that are based on judicious selection of animal species and strains, age group and individual animals are therefore an indispensable prerequisite to permit meaningful inference for humans, but for many animal species, only limited knowledge of geriatric processes is currently available.

The immunological and physiological changes that determine the increased susceptibility of geriatric individuals to infection are only partially understood, but seem to be predominantly associated with functional defects in the lymphocyte-macrophage system [242]. T-cell mediated immunity is decreased in aged individuals, probably primarily due to decreasing numbers of naïve $\mathrm{T}$ cells, higher expression of prostaglandin $\mathrm{E}_{2}$ by macrophages, and intrinsic changes in naïve and memory $\mathrm{T}$ cells such as decreased IL-2 secretion and T-cell receptor expression, increased expression of suppressors of cytokine signaling 
3, and defects in the T cell signaling pathway [243]. Phagocytic cells, including Kupfer cells, of geriatric individuals also generally appear to be impaired in their endocytic capacity [244]. Aged mice are more sensitive to LPS than younger animals, manifested as decreased $\mathrm{LD}_{50}$ values and increased expression of cytokines IL-1 $\alpha$, IL-6, IL-10 and TNF- $\alpha$ after LPS exposure [245]. Geriatric individuals therefore seem to differ from middle-aged adults in numerous ways. Importantly, nutritional factors such as vitamin $\mathrm{E}$ have been shown to enhance $\mathrm{T}$ cell-mediated functions in geriatric animals and humans, emphasizing the complexity of modeling geriatric disease [243].

Several studies have reported an increased susceptibility of geriatric animals to infection with L. monocytogenes [246]. Patel, for instance, inoculated 8 to 12 week and 24 to 28 month old backcrossed (A/Tru $\times \mathrm{C} 57 \mathrm{Bl} / 6)$ mice with $10^{3}$ to $10^{4} \mathrm{cfu}$ of $L$. monocytogenes strain EGD via the intravenous route, and detected higher bacterial loads in the liver and spleen of old mice [247]. In another study, Patel [144] found 24 month old (A/Tru $\times$ C57Bl/6) backcrossed mice inoculated with $L$. monocytogenes strain EGD more susceptible to infection than 8 month old mice of the same strain, with $\mathrm{LD}_{50}$ values equaling $1.6 \times 10^{5}$ and 4 $\times 10^{6}$, respectively. In transfusion experiments Patel determined that T-cells derived from geriatric $(\mathrm{A} / \mathrm{Tru} \times \mathrm{C} 57 \mathrm{Bl} /$ 6) backcrossed mice were 100 fold less efficient at protecting naïve mice from infection with $L$. monocytogenes strain EGD than $T$-cells derived from younger animals regardless of the age of the recipient mouse, and geriatric mice appeared to produce approximately 10 fold fewer protective T-cells than younger animals [236]. Aged mice of the $\mathrm{BALB} / \mathrm{c}$ strain were found to be increasingly susceptible to infection with $L$. monocytogenes after intravenous infection [233]. Notably, significant $(p<0.05)$ age-dependent differences after challenge with $10^{5} \mathrm{cfu}$ of $L$. monocytogenes were detected in mice as young as 11 month of age when compared to younger mice, but differences were considerably more pronounced in 18 than 11 month old mice [233]. Geriatric rats, 20 months of age, were more susceptible to pulmonary disease after intratreacheal inoculation with $L$. mononocytogenes strain $10403 \mathrm{~S}$ than younger rats 2.5 months of age [234]. Notably, all geriatric rats died within 6 days of intratracheal challenge with $5 \times 10^{5} \mathrm{cfu}$ of L. mononocytogenes strain 10403S, while $28 \%$ of younger rats were still alive 7 days after challenge, even though they succumbed to infection by day 8 post challenge [234].

Wu et al. [248] inoculated starved guinea pigs retired from breeding colonies (weighing approx. $1000 \mathrm{~g}$ ) and starved younger guinea pigs (weighing 250-300 g) with $100 \mathrm{CFU}$ of a L. monocytogenes serotype $4 \mathrm{~b}$ strain via oral gavage. Overall, $15 \%$ (i.e., 6/39) of geriatric animals and $8 \%(3 / 37)$ of younger animals developed infection based on pathogen detection in the liver and spleen, but none of the animals succumbed to infection, and only occasional mild gastro-intestinal symptoms developed in any of the animals [248]. Treatment with vitamin E appeared to have a protective effect for both geriatric and younger animals [248]. Similar results have also been described by Pang et al. [21], who analyzed the impact of vitamin $E$ on L. monocytogenes infection in approximately 2-year-old guinea pigs that had been retired from breeding colonies. Bruce et al. [235] reported somewhat impaired clearance of $L$. monocytogenes from the liver and spleen of vitamin D receptor knock-out mice compared to wild type mice of strain C57BL/6, again emphasizing the potential impact of nutritional factors.

Notably, on the contrary to the results presented above, some studies have reported an increased resistance of older mice to L. monocytogenes infection. Lovik et al. [237], for instance, reported an increased mean time to death (i.e., 6.7 vs. 4.7 days) and a decreased $\mathrm{LD}_{50}$ value $\left(6.4 \times 10^{5}\right.$ to $1.8 \times 10^{6}$ vs. $1.2 \times 10^{5}$ to $\left.8 \times 10^{5}\right)$ for 22 to 30 months compared to 11 to 16 week old (A/Tru $\times$ C57Bl/6) backcrossed mice inoculated intravenously with L. monocytogenes strain EGD. Gervais et al. [249] studied the susceptibility of 18 to 22 month old (A/J $\times$ C57BL/6 J) backcrossed mice to L. monocytogenes infection and reported diminished subcutaneous inflammatory responses compared to younger animals. Surprisingly, macrophages and Kupffer cells isolated from the older mice exhibited increased in-vitro antilisterial characteristics compared to cells isolated from younger mice, again indicating increased resistance of older mice to $L$. monocytogenes infection [249]. Several fundamental questions about the relevance of current geriatric models for the study of listeriosis therefore clearly remain.

\section{Conclusions and lessons learned}

In conclusion, the pathophysiology and immunology of L. monocytogenes infection is increasingly being elucidated, but several key components remain to be explained that may ultimately revolutionize our thinking about the adequacy of animal models for modeling disease in humans. Species-specific differences in Ecad and MET have been identified, but their definitive roles in the pathophysiology of listeriosis remain yet to be determined. As discussed above, rabbits and guinea pigs both appear to harbor MET receptors that cannot be activated by InlB, but rabbits seem considerably more susceptible to infection than guinea pigs and histopathological lesions in non-pregnant guinea pigs often appear localized in the myocardium. Murine and rat Ecad both carry the Pro16Glu mutation, while guinea pigs, rabbits and chickens do not. Yet, rats and guinea pigs appear considerably more resistant to L. monocytogenes infection than most mouse strains. Many questions regarding susceptibility differences among mouse strains, age groups, and L. monocytogenes strains also so far remain unresolved. 
Mouse models have been widely used for many decades and much of the currently available data on pathophysiology and immunology of L. monocytogenes infections has been generated in mice. However, recent findings cast doubt on the adequacy of this animal model, at least for certain aspects of infection. Novel, perhaps more appropriate animal models are currently being evaluated, but considerably more data has to be collected before the adequacy of these models can be evaluated comprehensively. Ideal animal models are biologically relevant, reliable, cost-effective, and sustain strict scientific and ethical scrutiny. Currently, no single animal model appears to fully meet all of these criteria and it appears that the most adequate animal model of human disease may have to be selected based on the specific aspect of infection to be studied, at least until more adequate animal models have been validated. A variety of animal species are susceptible to naturally occurring listeriosis, but the degree of susceptibility and the clinical manifestations appear to differ by species, physiological state, age group and L. monocytogenes strain. Perhaps with the exception of rhombencephalitis, invasive listeriosis appears to be an infection of immuno-compromised individuals - the young, the old, the pregnant and those with immune disorders appear to be at risk of developing disease. To date, it has been impossible to reliably reproduce the full spectrum of clinical disease in adult animals through experimental inoculation using relevant inoculation routes, regardless of the animal species, even when geriatric animals were used, multiple doses were given, or immune suppression was experimentally evoked in the animals. It thus appears that a more comprehensive understanding of the immunological determinants of susceptibility, as well as of the pathophysiology of infection, is needed before fully satisfactory animal models can be devised.

\subsection{Consequences for modeling $L$. monocytogenes dose- response}

Animal models have repeatedly been used to infer infectious or lethal doses for humans, estimates to be used in risk assessments or policy decisions. However, given the extraordinary variability in dose-response among animal species, the impact of L. monocytogenes strain-specific differences, and the numerous remaining questions about pathophysiology and immunology, it appears unclear which if any animal model is the most adequate to model human dose-response. Non-human primates may be the most relevant animal model for human dose-response, but so far only a limited number of experiments, restricted, due to ethical and practical considerations, to a small number of pregnant animals, L. monocytogenes strains, food matrices and only using application of a single dose (as opposed to multiple dosing), have been conducted. The available data with this animal model will only capture a limited amount of variability in dose-response relationships. Moreover, non-human primate doseresponse models are currently not available for elderly, immune-compromised or neonatal (i.e., late-onset listeriosis) cases, which together constitute a considerable fraction of human cases. In the absence of other data, data collected in mice and other animal species may possibly be substituted to infer measures of variability among $L$. monocytogenes strains, species, genetic backgrounds and immune conditions and to understand basic properties of the immune responses elicited in response to infection. However, such data has to be diligently tied to epidemiologic data collected among humans, results have to be interpreted in the light of emerging data on species-specific differences, and the limitations of such inferences have to be clearly acknowledged. Comparative studies, combining evidence collected in more than one susceptible animal species such as non-human primates or gerbils, may allow for more meaningful inference about human doseresponse. However, considerable differences in experimental design, disease outcome of interest, and genetic, physiological and immunological make-up of (often inbred) laboratory animals complicate comparisons across studies. Weight-of-evidence approaches may prove suitable to elucidate the impact of certain factors on dose response, such as for instance strain variability among mice. However, in the absence of a clear understanding of pathophysiology and immunology, weight-of evidence approaches may prove confusing or even misleading. The potential impact of various experimental conditions, such as the food matrix used for inoculation, the potential effect of antacids or starvation, the effect of repeated dosing - with short or long time intervals between doses -, the potential effect of microscopic lesions inflicted for instance during intragastric inoculation, and the true impact of L. monocytogenes strain - specific characteristics in different species or physiological stages, remain yet to be determined. However, such data will be vital to adequately evaluate the biological relevance of a given animal model for human disease.

In summary, much has been learned about L. monocytogenes since its first isolation from naturally infected rodents, but truly suitable animal models of infection are so far still missing, and many uncertainties remain when animal models are employed to model human infection.

\section{Endnotes}

${ }^{\mathrm{a} E} 16 \mathrm{PmE}$ cad mice were generated by crossing germline chimeras (i.e., chimeras between: i) transgenic CK35 embryonic stem (ES) cells - an ES cell line derived from murine strain $129 / \mathrm{Sv}$ [250]- that were genetically modified to express murine E-cadherin with the E16P mutation (i.e., 'humanized' E-cadherin), and ii) C57BL/6 blastocystes) with mice transgenic for the Cre site-specific recombinase 
that were generated in the $\mathrm{BALB} / \mathrm{c} \times \mathrm{C} 57 \mathrm{~B} 1 / \mathrm{B} 6$ background [12,251].

bi.e., HeLa (origin: human cervical adenocarcinoma), Nme (derived from NMuMG cells, an immortalized line of mouse mammary epithelial cells $[180,184])$, RK13 (origin: rabbit kidney cells), GPC16 (origin: guinea pig colorectal adenocarcinoma), 104 (origin: guinea pig fetal fibroblast) and JH4 (origin: guinea pig lung fibroblast) cells.

\section{Acknowledgements}

We are grateful to David Weingaertner for his graphical expertise in creating the figure. This work was supported in part by appointments to the Research Participation Program at the Center for Food Safety and Applied Nutrition administered by the Oak Ridge Institute for Science and Education through an interagency agreement between the US Department of Energy and the US Food and Drug Administration.

\section{Authors' contributions}

$\mathrm{SD}, \mathrm{KH}$ and RP conceived and planned the study and participated in the decision to publish. $\mathrm{KH}$ reviewed the literature and $\mathrm{KH}$ and $\mathrm{RP}$ prepared the manuscript. All authors read and approved the manuscript.

\section{Competing interests}

The authors declare that they have no competing interests.

Received: 8 November 2011 Accepted: 14 March 2012

Published: 14 March 2012

\section{References}

1. Scallan E, Hoekstra RM, Angulo FJ, Tauxe RV, Widdowson MA, Roy SL, Jones JL, Griffin PM: Foodborne illness acquired in the United Statesmajor pathogens. Emerg Infect Dis 2011, 17:7-15.

2. Food and Agriculture Organization of the United Nations, Viale delle Terme di Caracalla, 00100 Rome, Italy, and World Health Organization, 20 Avenue Appia, CH-1211 Geneva 27, Switzerland.

3. Mook P, O'Brien SJ, Gillespie IA: Concurrent conditions and human listeriosis, England, 1999-2009. Emerg Infect Dis 2011, 17:38-43.

4. Goulet V, Marchetti P: Listeriosis in 225 non-pregnant patients in 1992: clinical aspects and outcome in relation to predisposing conditions. Scand J Infect Dis 1996, 28:367-374.

5. Painter J, Slutsker L: Listeriosis in humans. In Listeria, Listeriosis and Food Safety. 3 edition. Edited by: Ryser ET, Marth EH. Boca Raton: CRC Press; 2007:85-109.

6. Vazquez-Boland JA, Kuhn M, Berche P, Chakraborty T, Dominguez-Bernal G, Goebel W, Gonzalez-Zorn B, Wehland J, Kreft J: Listeri pathogenesis and molecular virulence determinants. Clin Microbiol Rev 2001, 14:584-640.

7. Buchanan RL, Damert WG, Whiting RC, van Schothorst M: Use of epidemiologic and food survey data to estimate a purposefully conservative dose-response relationship for Listeria monocytogene levels and incidence of listeriosis. J Food Protect 1997, 60:918-922.

8. Hamon M, Bierne $\mathrm{H}$, Cossart P: Listeria monocytogene: a multifaceted model. Nat Rev Microbiol 2006, 4:423-434.

9. FDA/FSIS: Quantitative Assessment of Relative Risk to Public Health from Foodborne Listeria monocytogenes Among Selected Categories of Readyto-Eat Foods. FDA (Food and Drug Administration), USDA -FSIS (United States Department of Agriculture Food Safety Inspection Service), and CDC (Centers for Disease Control and Prevention); 2003 [http://www.fda.gov/ Food/ScienceResearch/ResearchAreas/RiskAssessmentSafetyAssessment/ ucm183966.htm].

10. Gellin BG, Broome CV: Listeriosis. JAMA 1989, 261:1313-1320.

11. Lecuit M: Human listeriosis and animal models. Microbes Infect 2007, 9:1216-1225

12. Disson $\mathrm{O}$, Grayo $\mathrm{S}$, Huillet $E$, Nikitas $G$, Langa-Vives F, Dussurget $\mathrm{O}$, Ragon M, Le Monnier A, Babinet C, Cossart P, Lecuit M: Conjugated action of two species-specific invasion proteins for fetoplacental listeriosis. Nature 2008, 455:1114-1118.
13. Smith MA, Takeuchi K, Anderson G, Ware GO, McClure HM, Raybourne RB, Mytle N, Doyle MP: Dose-response model for Listeria monocytogeneinduced stillbirths in nonhuman primates. Infect Immun 2008, 76:726-731.

14. Smith MA, Takeuchi K, Brackett RE, McClure HM, Raybourne RB, Williams KM, Babu US, Ware GO, Broderson JR, Doyle MP: Nonhuman primate model for Listeria monocytogene-induced stillbirths. Infect Immun 2003, 71:1574-1579.

15. Farber JM, Daley E, Coates F, Beausoleil N, Fournier J: Feeding trials of Listeria monocytogene with a nonhuman primate model. J Clin Microbiol 1991, 29:2606-2608.

16. Williams D, Irvin EA, Chmielewski RA, Frank JF, Smith MA: Dose-response of Listeria monocytogene after oral exposure in pregnant guinea pigs. $J$ Food Prot 2007, 70:1122-1128.

17. Pine L, Malcolm GB, Plikaytis BD: Listeria monocytogene intragastric and intraperitoneal approximate $50 \%$ lethal doses for mice are comparable, but death occurs earlier by intragastric feeding. Infect Immun 1990, 58:2940-2945.

18. Stelma GN Jr, Reyes AL, Peeler JT, Francis DW, Hunt JM, Spaulding PL, Johnson CH, Lovett J: Pathogenicity test for Listeria monocytogene using immunocompromised mice. J Clin Microbiol 1987, 25:2085-2089.

19. Pine L, Weaver RE, Carlone GM, Pienta PA, Rocourt J, Goebel W, Kathariou S, Bibb WF, Malcolm GB: Listeria monocytogene ATCC 35152 and NCTC 7973 contain a nonhemolytic, nonvirulent variant. J Clin Microbiol 1987, 25:2247-2251.

20. Matsumoto T, Miake S, Mitsuyama M, Takeya K, Nomoto K: Enhanced resistance to Listeria monocytogene due to non-specifically activated macrophages in aged mice. J Clin Lab Immunol 1982, 8:51-54.

21. Pang HJ, Lo CY, Matthews KR: Influence of immunomodulation on the development of Listeria monocytogene infection in aged guinea pigs. FEMS Immunol Med Microbiol 2007, 49:415-424.

22. Botzler RG, Wetzler TF, Cowan AB: Listeri in aquatic animals. J Wildl Dis 1973, 9:163-170.

23. Gray ML, Killinger AH: Listeria monocytogene and listeric infections. Bacteriol Rev 1966, 30:309-382.

24. Lecuit M: Understanding how Listeria monocytogene targets and crosses host barriers. Clin Microbiol Infect 2005, 11:430-436.

25. Pron B, Boumaila C, Jaubert F, Sarnacki S, Monnet JP, Berche P, Gaillard JL: Comprehensive study of the intestinal stage of listeriosis in a rat ligated ileal loop system. Infect Immun 1998, 66:747-755.

26. Marco AJ, Prats N, Ramos JA, Briones V, Blanco M, Dominguez $\mathrm{L}$, Domingo M: A microbiological, histopathological and immunohistological study of the intragastric inoculation of Listeria monocytogene in mice. J Comp Pathol 1992, 107:1-9.

27. Marco AJ, Altimira J, Prats N, Lopez S, Dominguez L, Domingo M, Briones V: Penetration of Listeria monocytogene in mice infected by the oral route. Microb Pathog 1997, 23:255-263.

28. Racz P, Tenner K, Mero E: Experimental Listeri enteritis. I. An electron microscopic study of the epithelial phase in experimental listeria infection. Lab Invest 1972, 26:694-700.

29. Portnoy DA, Auerbuch V, Glomski IJ: The cell biology of Listeria monocytogene infection: the intersection of bacterial pathogenesis and cell-mediated immunity. J Cell Biol 2002, 158:409-414.

30. Pamer EG: Immune responses to Listeria monocytogene. Nat Rev Immunol 2004, 4:812-823.

31. Neutra MR, Mantis NJ, Kraehenbuhl JP: Collaboration of epithelial cells with organized mucosal lymphoid tissues. Nat Immunol 2001, 2:1004-1009

32. Yoshikai Y: The interaction of intestinal epithelial cells and intraepithelial lymphocytes in host defense. Immunol Res 1999, 20:219-235.

33. Pron B, Boumaila C, Jaubert F, Berche P, Milon G, Geissmann F, Gaillard JL: Dendritic cells are early cellular targets of Listeria monocytogene after intestinal delivery and are involved in bacterial spread in the host. Cell Microbiol 2001, 3:331-340.

34. Gregory SH, Sagnimeni AJ, Wing EJ: Bacteria in the bloodstream are trapped in the liver and killed by immigrating neutrophils. J Immunol 1996, 157:2514-2520.

35. Gregory SH, Wing EJ: Neutrophil-Kupffer cell interaction: a critical component of host defenses to systemic bacterial infections. J Leukoc Biol 2002, 72:239-248.

36. Gaillard $J L$, Jaubert F, Berche P: The in/A locus mediates the entry of Listeria monocytogene into hepatocytes in vivo. J Exp Med 1996, 183:359-369. 
37. Appelberg R, Leal IS: Mutants of Listeria monocytogene defective in in vitro invasion and cell-to-cell spreading still invade and proliferate in hepatocytes of neutropenic mice. Infect Immun 2000, 68:912-914.

38. Dramsi S, Biswas I, Maguin E, Braun L, Mastroeni P, Cossart P: Entry of Listeria monocytogene into hepatocytes requires expression of inIB, a surface protein of the internalin multigene family. Mol Microbiol 1995, 16:251-261.

39. Braun L, Ohayon $H$, Cossart P: The InIB protein of Listeria monocytogene is sufficient to promote entry into mammalian cells. Mol Microbiol 1998, 27:1077-1087.

40. Mackaness GB: Cellular resistance to infection. J Exp Med 1962, 116:381-406

41. Kuhn M, Scortti M, Vazquez-Boland A: Pathogenesis. In Handbook of Listeria monocytogenes. Edited by: Liu D. Boca Raton: CRC Press, Taylor and Francis Group; 2008:.

42. Conlan JW: Early pathogenesis of Listeria monocytogene infection in the mouse spleen. J Med Microbiol 1996, 44:295-302.

43. Aoshi T, Carrero JA, Konjufca V, Koide Y, Unanue ER, Miller MJ: The cellular niche of Listeria monocytogene infection changes rapidly in the spleen. Eur J Immunol 2009, 39:417-425.

44. Merrick JC, Edelson BT, Bhardwaj V, Swanson PE, Unanue ER: Lymphocyte apoptosis during early phase of Listeri infection in mice. Am J Pathol 1997, 151:785-792.

45. Khelef $N$, Lecuit M, Bierne $H$, Cossart P: Species specificity of the Listeria monocytogene InIB protein. Cell Microbiol 2006, 8:457-470.

46. Tunkel AR, Scheld WM: Pathogenesis and pathophysiology of bacterial meningitis. Clin Microbiol Rev 1993, 6:118-136.

47. Wilson SL, Drevets DA: Listeria monocytogene infection and activation of human brain microvascular endothelial cells. J Infect Dis 1998, 178:1658-1666.

48. Parida SK, Domann E, Rohde M, Muller S, Darji A, Hain T, Wehland J, Chakraborty T: Internalin B is essential for adhesion and mediates the invasion of Listeria monocytogene into human endothelial cells. Mol Microbiol 1998, 28:81-93.

49. Greiffenberg L, Sokolovic Z, Schnittler HJ, Spory A, Böckmann R, Goebel W, Kuhn M: Listeria monocytogene-infected human umbilical vein endothelial cells: internalin-independent invasion, intracellular growth, movement, and host cell responses. FEMS Microbiol Lett 1997 157:163-170.

50. Greiffenberg L, Goebel W, Kim KS, Weiglein I, Bubert A, Engelbrecht F, Stins M, Kuhn M: Interaction of Listeria monocytogene with human brain microvascular endothelial cells: InIB-dependent invasion, long-term intracellular growth, and spread from macrophages to endothelial cells. Infect Immun 1998, 66:5260-5267.

51. Drevets DA, Sawyer RT, Potter TA, Campbell PA: Listeria monocytogene infects human endothelial cells by two distinct mechanisms. Infect Immun 1995, 63:4268-4276.

52. Kim KS: Mechanisms of microbial traversal of the blood-brain barrier. Nat Rev Microbiol 2008, 6:625-634.

53. Bakardjiev Al, Stacy BA, Portnoy DA: Growth of Listeria monocytogene in the guinea pig placenta and role of cell-to-cell spread in fetal infection. $J$ Infect Dis 2005, 191:1889-1897.

54. Lamont RF, Sobel J, Mazaki-Tovi S, Kusanovic JP, Vaisbuch E, Kim SK, Uldbjerg N, Romero R: Listeriosis in human pregnancy: a systematic review. J Perinat Med 39:227-236.

55. Ryser ET, Marth EM: Listeria, Listeriosis, and Food Safety. 3 edition. Boca Raton, Fl: Taylor \& Francis Group; 2007.

56. Hume OS: Maternal Listeria monocytogene septicemia with sparing of the fetus. Obstet Gynecol 1976, 48(1 Suppl):33S-34S.

57. Smith ARB, Lieberman BA, Allen L, Barson A: Listeriosis and pregnancy. Lancet 1983, 322:1364.

58. Mylonakis E, Paliou M, Hohmann EL, Calderwood SB, Wing EJ: Listeriosis during pregnancy: a case series and review of 222 cases. Medicine 2002, 81:260-269.

59. Janakiraman V: Listeriosis in pregnancy: diagnosis, treatment, and prevention. Rev Obstet Gynecol 2008, 1:179-185.

60. Spencer JA: Perinatal listeriosis. Br Med J (Clin Res Ed) 1987, 295:349.

61. Schlech WF, Acheson D: Foodborne Listeriosis. Clin Infect Dis 2000, 31:770-775.

62. Smith JL: Foodborne infections during pregnancy. J Food Prot 1999, 62:818-829.
63. Nelson KE, Warren D, Tomasi AM, Raju TN, Vidyasagar D: Transmission of neonatal listeriosis in a delivery room. Am J Dis Child 1985, 139:903-905.

64. Filice GA, Cantrell HF, Smith AB, Hayes PS, Feeley JC, Fraser DW: Listeria monocytogene infection in neonates: investigation of an epidemic. J Infect Dis 1978, 138:17-23.

65. Simmons MD, Cockcroft PM, Okubadejo OA: Neonatal listeriosis due to cross-infection in an obstetric theatre. J Infect 1986, 13:235-239.

66. Doganay M: Listeriosis: clinical presentation. FEMS Immunol Med Microbiol 2003, 35:173-175.

67. Gerner-Smidt P, Ethelberg S, Schiellerup P, Christensen JJ, Engberg J, Fussing V, Jensen A, Jensen C, Petersen AM, Bruun BG: Invasive listeriosis in Denmark 1994-2003: a review of 299 cases with special emphasis on risk factors for mortality. Clin Microbiol Infect 2005, 11:618-624.

68. Clauss HE, Lorber B: Central nervous system infection with Listeria monocytogene. Curr Infect Dis Rep 2008, 10:300-306.

69. Bartt R: Listeri and atypical presentations of Listeri in the central nervous system. Semin Neurol 2000, 20:361-373.

70. Ooi ST, Lorber B: Gastroenteritis due to Listeria monocytogene. Clin Infect Dis 2005, 40:1327-1332.

71. Armstrong RW, Fung PC: Brainstem encephalitis (rhombencephalitis) due to Listeria monocytogene: case report and review. Clin Infect Dis 1993, 16:689-702.

72. Visser IJ: Pustular dermatitis in veterinarians following delivery in domestic animals; an occupational disease. Tijdschr Geneeskd 1996, 140:1186-1190, (in Dutch).

73. Murray EGD, Webb RA, Swann MBR: A disease of rabbits characterized by large mononuclear leucocytosis, caused by a hitherto undescribed bacillus Bacterium monocytogenes (n. sp.). J Pathol Bacteriol 1926, 29:407-439.

74. Cordy DR, Osebold JW: The neuropathogenesis of Listeri encephalomyelitis in sheep and mice. J Infect Dis 1959, 104:164-173.

75. Silverman SJ, Elwell LP, Drawdy JF: Influence of route of infection and other factors on growth and distribution of Listeria monocytogene in organs of mice. J Bacteriol 1963, 86:355-362.

76. Gray ML: Listeriosis in fowls: a review. Avian Dis 1958, 2:296-314.

77. Low JC, Donachie W: A review of Listeria monocytogene and listeriosis Vet J 1997, 153:9-29.

78. Schlech WF, Lavigne PM, Bortolussi RA, Allen AC, Haldane EV, Wort AJ, Hightower AW, Johnson SE, King SH, Nicholls ES, Broome CV: Epidemic listeriosis-evidence for transmission by food. N Engl J Med 1983, 308:203-206.

79. Gyles CL, Prescott JF, Songer G, Thoen CO: Pathogenesis of bacterial infections in animals. 4 edition. Ames: Wiley-Blackwell; 2010

80. Eriksen L, Larsen HE, Christiansen T, Jensen MM, Eriksen E: An outbreak of meningo-encephalitis in fallow deer caused by Listeria monocytogene. Vet Rec 1988, 122:274-276.

81. Archibald RM: Listeria monocytogene from a Nova Scotia Moose. Can Vet $J$ 1960, 1:225-226.

82. Esteban Jl, Oporto B, Aduriz G, Juste RA, Hurtado A: Faecal shedding and strain diversity of Listeria monocytogene in healthy ruminants and swine in Northern Spain. BMC Vet Res 2009, 5:2.

83. Ho AJ, Ivanek R, Grohn YT, Nightingale KK, Wiedmann M: Listeria monocytogenes fecal shedding in dairy cattle shows high levels of dayto-day variation and includes outbreaks and sporadic cases of shedding of specific L. monocytogenes subtypes. Prev Vet Med 2007, 80:287-305.

84. Brugère-Picoux J: Ovine listeriosis. Small Ruminant Res 2008, 76:12-20.

85. Kumar H, Singh BB, Bal MS, Kaur K, Singh R, Sidhu PK, Sandhu KS: Pathological and epidemiological investigations into listerial encephalitis in sheep. Small Ruminant Res 2007, 71:293-297.

86. Kah CM, Scott L: Listeriosis. The Merk Veterinary Manual. 10 edition. Rahway: Merk Publishing; 2010.

87. Sanaa M, Poutrel B, Menard JL, Serieys F: Risk factors associated with contamination of raw milk by Listeria monocytogene in dairy farms. $J$ Dairy Sci 1993, 76:2891-2898.

88. Oevermann A, Zurbriggen A, Vandevelde M: Rhombencephalitis caused by Listeria monocytogene in humans and ruminants: a zoonosis on the rise? Interdiscip Perspect Infect Dis 2010, 2010:632513.

89. Schroeder H, van Rensburg IB: Generalised Listeria monocytogene infection in a dog. J S Afr Vet Assoc 1993, 64:133-136.

90. Evans K, Smith M, McDonough P, Wiedmann M: Eye infections due to Listeria monocytogene in three cows and one horse. J Vet Diagn Invest 2004, 16:464-469. 
91. Wuthe HH, Schoenberg A: Listeriosis in the European brown hare in northern Germany. Berl Muench Tieraerztl Wschr 1999, 112:98-99, (in German).

92. Pirie JH: New disease of veld rodents "Tiger River disease". Pub/ S African Inst Med Res 1927, 3:163-186.

93. Plagemann O, Wageman A: Listeria monocytogene als Abortursache bei Klippschliefern. Kleintierpraxis 1988, 33:317-318, (in German).

94. Jacotot $H$, Vallee A, Virat B: Une epizootie de listerellose dans un élevage de chinchillas. Bull Acad Vet 1956, 29:427-430, (in French).

95. Vallee A: Un cas de Listeriose du Lièvre en France. Ann Inst Pasteur 1952, 83:832-833, (in French)

96. Yoshida T, Sugimoto T, Sato M, Hirai K: Incidence of Listeria monocytogene in wild animals in Japan. J Vet Med Sci 2000, 62:673-675.

97. Olsufev NG, Emelyanova OS: Detection of Listerella infection in wild rodents, insectivora and ixodes ticks. O'suffay 1951, 22:67-71.

98. Berche P, Brisabois A, Catteau M, Flandrois JP, Labadie JC, Rocourt J, Salvat G, Vaillant V, Vidon DJ, Vranckx R: Rapport de la Commission d'étude des risques liés à Listeria monocytogenes. Paris; 2000 [http://www. anses.fr/Documents/MIC-Ra-Listeria2000.pdf], Editor by Agence Française de Sécurité Sanitaire des Aliments (in French).

99. Moerner T: Monitoring disease in wildlife - a review of diseases in the orders lagomorpha and rodentia in Sweden. Verhber Erkg Zootiere 1999, 39:255-262.

100. Tappe JP, Chandler FW, Westrom WK, Liu SK, Dolensek EP: Listeriosis in seven bushy-tailed jirds. J Am Vet Med Assoc 1984, 185:1367-1370.

101. Finley GG, Long JR: An epizootic of listeriosis in chinchillas. Can Vet J 1977, 18:164-167.

102. Watson GL, Evans MG: Listeriosis in a rabbit. Vet Pathol 1985, 22:191-193.

103. Peters M, Scheele G: Listeriosis in a rabbitry. Dtsch Tierarztl Wochenschr 1996, 103:460-462, (in German).

104. Ghenne P, Fievez L, Granville A: La Listeriose du Chinchilla. Ann Med Vet 1969, 113:294-301, (in French).

105. Wilkerson MJ, Melendy A, Stauber E: An outbreak of listeriosis in a breeding colony of chinchillas. J Vet Diagnost Invest 1997, 9:320-323.

106. Kalter SS: Infectious diseases of nonhuman primates in a zoo setting. Zoo Biol 1989, 8:61-76.

107. McClure HM, Strozier LM: Perinatal listeric septicemia in a Celebese black ape. J Am Vet Med Assoc 1975, 167:637-638.

108. Heldstab A, Rüedi D: Listeriosis in an adulte female chimpanzee (Pan troglodytes). J Comp Pathol 1982, 92:609-612.

109. Pinkerton ME: Bacteremia in wild baboon. Bact Proc 1967, 67:67.

110. Vetesi F, Balsai A, Kemenes F: Proceedings: abortion in Gray's monkey (Cercopithecus mona) associated with Listeria monocytogene. Acta Microbiol Acad Sci Hung 1972, 19:441-443.

111. Chalifoux LV, Hajema EM: Septicemia and meningoencephalitis caused by Listeria monocytogene in a neonatal Macaca fascicularis. J Med Primatol 1981, 10:336-339.

112. Bloom W: The formation of abscesses in an infection with Bacterium monocytogenes. Arch Pathol 1928, 6:995-1007.

113. Osebold JW, Inouye T: Pathogenesis of Listeria monocytogene infections in natural hosts: I. Rabbit studies. J Infect Dis 1954, 95:52-66.

114. Kautter DA, Silverman SJ, Roessler WG: Studies on the virulence of Listeria monocytogene via the respiratory route for laboratory animals. Bacteriol Proc 1959, 1959:95.

115. Kautter DA, Silverman SJ, Roessler WG, Drawdy JF: Virulence of Listeria monocytogene for experimental animals. J Infect Dis 1963, 112:167-180.

116. Urbach H, Schabinski G: Zur Listeriose des Menschen. Zeitschr f Hygiene 1955, 141:239-248, (in German).

117. Gray ML, Stafseth HJ, Thorp F, Sholl LB, Riley WF: A new technique for isolating Listerellae from the bovine brain. J Bacterio/ 1948, 55:471-476

118. Gray ML, Laine SL, Thorp F: The effect of aureomycine on Listeria monocytogene and the production of encephalitic symptoms in rabbits. Antibiot Chemotherapy 1952, 2:537-543.

119. Flamm H, Zehetrauer $\mathrm{G}$ : Listeriosis of the eye in experimental animals. Albrecht von Graefe's Archiv fuer Opthalmologie 1956, 158:122-135, (in German).

120. Morris $M C$, Julianelle LA: A study of an ocular infection induced experimentally with bacterium monocytogenes. Am J Ophthalmol 1935, 18:535-541.

121. Graham R, Levine ND, Morrill CC: Listerellosis in domestic animals: a technical discussion of field and laboratory investigations. Bulletin 499: University of Illinois Agricultural Experiment Stataion; 1943.
122. Hahnefeld $\mathrm{H}$, Hahnefeld $\mathrm{E}$ : In Untersuchungen zur Frage der peroralen Listeria-monocytogenes-Infektion bei Kaninchen mit besonderer Beruecksichtigung der Graviditaet. Volume 13. Leipzig: S Hirzel Verlag Leipzig; 1959, (in German).

123. Nordland OS, Nordland OS: Host Parasite Relations in Initiation of Infection: II. Hyperglycemia and Stress in Experimental Infection with $L$. monocytogene. Can J Comp Med Vet Sci 1960, 24:57-75.

124. Gray ML: Experimental listeriosis in pregnant animals. Beiheft I, Zntr. Veterinaermed. Berlin: Paul Paray Verlag; 1958.

125. Payne JM: Changes in the rat placenta and foetus following experimental infection with various species of bacteria. J Pathol Bacteriol 1958, 75:367-385.

126. Suchnova M, Mencikova E, Patocka F, Benesova D: Experimentelle Listeriose der Kaninchen. Verlauf der experimentalen Infektion und Studium ihrer Uebertragung von der Mutter auf die Frucht. Zentr Bakteriol Parasitenk Abt I Orig 1958, 170:547-564, (in German).

127. Okamoto $M$, Nakane $A$, Minagawa $T$ : Host resistance to an intragastric infection with Listeria monocytogene in mice depends on cellular immunity and intestinal bacterial flora. Infect Immun 1994, 62:3080-3085.

128. Schlech WF: An animal model of foodborne Listeria monocytogene virulence: effect of alterations in local and systemic immunity on invasive infection. Clin Invest Med 1993, 16:219-225.

129. Lee HY, Park JH, Seok SH, Baek MW, Kim DJ, Lee BH, Kang PD, Kim YS: Potential antimicrobial effects of human lactoferrin against oral infection with Listeria monocytogene in mice. J Med Microbiol 2005, 54:1049-1054.

130. Manohar M, Baumann DO, Bos NA, Cebra JJ: Gut colonization of mice with actA-negative mutant of Listeria monocytogene can stimulate a humoral mucosal immune response. Infect Immun 2001, 69:3542-3549.

131. Altimira J, Prats $N$, Lopez S, Domingo M, Briones $V$, Dominguez $L$, Marco A: Repeated oral dosing with Listeria monocytogene in mice as a model of central nervous system listeriosis in man. J Comp Pathol 1999, 121:117-125.

132. Garifulin O, Qi Z, Shen H, Patnala S, Green MR, Boyartchuk V: Polymorphism alters induction of interferon beta in response to Listeria monocytogene infection. PLOS Genet 2007, 3:e152.

133. Kongshavn PAL: Genetic control of murine listeriosis expressed in the macrophage response. Immunol Lett 1985, 11:181-188.

134. Lawrence DA, Schell RF: Susceptibility of C5-deficient mice to listeriosis: modulation by concanavalin A. Cell Immunol 1978, 39:336-344.

135. Munder A, Zelmer A, Schmiedl A, Dittmar KEJ, Rohde M, Dorsch M, Otto K, Hedrich HJ, Tümmler B, Weiss $S$, Tschernig T: Murine pulmonary infection with Listeria monocytogene: differential susceptibility of BALB/c, C57BL/6 and DBA/2 mice. Microbes Infect 2005, 7:600-611.

136. Kim SH, Bakko MK, Knowles D, Borucki MK: Oral inoculation of A/J mice for detection of invasiveness differences between Listeria monocytogene epidemic and environmental strains. Infect Immun 2004, 72:4318-4321.

137. Czuprynski CJ, Faith NG, Steinberg H: A/J mice are susceptible and C57BL/ 6 mice are resistant to Listeria monocytogene infection by intragastric inoculation. Infect Immun 2003, 71:682-689.

138. Cheers C, McKenzie IF: Resistance and susceptibility of mice to bacterial infection: genetics of listeriosis. Infect Immun 1978, 19:755-762.

139. Mainou-Fowler T, MacGowan AP, Postlethwaite R: Virulence of Listeria spp: course of infection in resistant and susceptible mice. J Med Microbiol 1988, 27:131-140.

140. Archinal WA, Wilder MS: Susceptibility of HRS/J mice to listeriosis: dynamics of infection. Infect Immun 1988, 56:607-612.

141. Skamene E, Kongshavn PA, Sachs DH: Resistance to Listeria monocytogene in mice: genetic control by genes that are not linked to the $\mathrm{H}-2$ complex. J Infect Dis 1979, 139:228-231.

142. Liu D: Listeria monocytogene: comparative interpretation of mouse virulence assay. FEMS Microbiol Lett 2004, 233:159-164.

143. Erdenlig S, Ainsworth AJ, Austin FW: Pathogenicity and production of virulence factors by Listeria monocytogene isolates from channel catfish. J Food Prot 2000, 63:613-619.

144. Patel PJ: Aging and cellular defense mechanisms: age-related changes in resistance of mice to Listeria monocytogene. Infect Immun 1981, 32:557-562.

145. Salerno JA, Waltenbaugh C, Cianciotto NP: Ethanol consumption and the susceptibility of mice to Listeria monocytogene infection. Alcohol Clin Exp Res 2001, 25:464-472 
146. Hardy J, Francis KP, DeBoer M, Chu P, Gibbs K, Contag CH: Extracellular Replication of Listeria monocytogene in the Murine Gall Bladder. Science 2004, 303:851-853.

147. Kerckhaert JA, Hofhuis FM, Willers JM: Influence of cyclophosphamide on delayed hypersensitivity and acquired cellular resistance to Listeria monocytogene in the mouse. Immunology 1977, 32:1027-1032.

148. Buchmeier NA, Schreiber RD: Requirement of endogenous interferongamma production for resolution of Listeria monocytogene infection. Proc Natl Acad Sci 1985, 82:7404-7408.

149. Lecuit M, Vandormael-Pournin S, Lefort J, Huerre M, Gounon P, Dupuy C, Babinet $C$, Cossart P: A transgenic model for listeriosis: role of internalin in crossing the intestinal barrier. Science 2001, 292:1722-1725.

150. Wagner R, Czuprynski C: Cytokine mRNA expression in livers of mice infected with Listeria monocytogene. J Leukoc Biol 1993, 53:525-531.

151. Cossart P, Vicente MF, Mengaud J, Baquero F, Perez-Diaz JC, Berche P: Listeriolysin is essential for virulence of Listeria monocytogene: direct evidence obtained by gene complementation. Infect Immunity 1989, 57:3629-3636.

152. Takeuchi K, Mytle N, Lambert S, Coleman M, Doyle MP, Smith MA: Comparison of Listeria monocytogene virulence in a mouse model. $J$ Food Prot 2006, 69:842-846.

153. Xiong H, Kawamura I, Nishibori T, Mitsuyama M: Cytokine gene expression in mice at an early stage of infection with various strains of Listeria spp differing in virulence. Infect Immun 1994, 62:3649-3654.

154. Lammerding AM, Glass KA, Gendron-Fitzpatrick A, Doyle MP: Determination of virulence of different strains of Listeria monocytogene and Listeria innocu by oral inoculation of pregnant mice. Appl Environ Microbiol 1992, 58:3991-4000.

155. Wilkinson TR, Hall ER: Survival of Listeria monocytogene in experimentally infected mice. Appl Microbiol 1971, 21:108-111.

156. Emmerling $P$, Finger $H$, Bockemuhl J: Listeria monocytogene infection in nude mice. Infect Immun 1975, 12:437-439.

157. Emmerling $P$, Finger $H$, Hof $H$ : Cell-mediated resistance to infection with Listeria monocytogene in nude mice. Infect Immun 1977, 15:382-385.

158. von Koenig $\mathrm{CH}$, Heymer $\mathrm{B}$, Hof $\mathrm{H}$, Finger $\mathrm{H}$ : Course of infection and development of immunity in experimental infection of mice with Listeri serotypes. Infect Immun 1983, 40:1170-1177.

159. Mérino D, Réglier-Poupet H, Berche P, The European Listeria Genome C, Charbit A: A hypermutator phenotype attenuates the virulence of Listeria monocytogene in a mouse model. Mol Microbiol 2002, 44:877-887.

160. Bracegirdle P, West AA, Lever MS, Fitzgeorge RB, Baskerville A: A comparison of aerosol and intragastric routes of infection with Listeria sp. Epidemiol Infect 1994, 112:69-79.

161. Utermohlen O, Karow U, Lohler J, Kronke M: Severe impairment in early host defense against Listeria monocytogene in mice deficient in acid sphingomyelinase. J Immunol 2003, 170:2621-2628.

162. Park JH, Park YH, Seok SH, Cho SA, Kim DJ, Lee HY, Kim SH: Suppurative gastritis in BALB/c mice infected with Listeria monocytogene via the intragastric route. J Comp Pathol 2004, 130:130-136.

163. Mandel TE, Cheers $C$ : Resistance and susceptibility of mice to bacterial infection: histopathology of listeriosis in resistant and susceptible strains. Infect Immun 1980, 30:851-861.

164. Gervais F, Stevenson M, Skamene E: Genetic control of resistance to Listeria monocytogenes regulation of leukocyte inflammatory responses by the $H$ locus. J Immunol 1984, 132:2078-2083.

165. Gervais F, Desforges C, Skamene E: The C5-sufficient A/J congenic mouse strain. Inflammatory response and resistance to Listeria monocytogenes. J Immunol 1989, 142:2057-2060.

166. Liu T, Nishimura H, Matsuguchi T, Yoshikai Y: Differences in interleukin-12 and -15 production by dendritic cells at the early stage of Listeria monocytogene infection between BALB/C and C57 BL/6 mice. Cell Immunol 2000, 202:31-40

167. lizawa Y, Wagner RD, Czuprynski CJ: Analysis of cytokine mRNA expression in Listeri-resistant C57BL/6 and Listeri-susceptible A/J mice during Listeria monocytogene infection. Infect Immun 1993, 61:3739-3744.

168. Pasche B, Kalaydjiev S, Franz TJ, Kremmer E, Gailus-Durner V, Fuchs H, Hrabe de Angelis $M$, Lengeling $A$, Busch $\mathrm{DH}$ : Sex-dependent susceptibility to Listeria monocytogene infection is mediated by differential interleukin-10 production. Infect Immun 2005, 73:5952-5960.
169. Barbour AH, Rampling A, Hormaeche CE: Variation in the infectivity of Listeria monocytogene isolates following intragastric inoculation of mice. Infect Immun 2001, 69:4657-4660.

170. Czuprynski CJ, Faith NG, Steinberg H: Ability of the Listeria monocytogene strain scott a to cause systemic infection in mice infected by the intragastric route. Appl Environ Microbiol 2002, 68:2893-2900.

171. Roll JT, Czuprynski CJ: Hemolysin is required for extraintestinal dissemination of Listeria monocytogene in intragastrically inoculated mice. Infect Immun 1990, 58:3147-3150.

172. Cossart P, Pizarro-Cerdá J, Lecuit M: Invasion of mammalian cells by Listeria monocytogene: functional mimicry to subvert cellular functions. Trends Cell Biol 2003, 13:23-31.

173. Dussurget O, Pizarro-Cerda J, Cossart P: Molecular determinants of Listeria monocytogene virulence. Annu Rev Microbiol 2004, 58:587-610.

174. Bierne H, Sabet C, Personnic N, Cossart P: Internalins: a complex family of leucine-rich repeat-containing proteins in Listeria monocytogene. Microbes Infect 2007, 9:1156-1166.

175. Gaillard $J$, Berche P, Frehel C, Gouin E, Cossart P: Entry of $L$. monocytogene into cells is mediated by internalin, a repeat protein reminiscent of surface antigens from gram-positive cocci. Cell 1991, 65:1127-1141.

176. Cossart $\mathrm{P}$, Lecuit M: Interactions of Listeria monocytogene with mammalian cells during entry and actin-based movement: bacterial factors, cellular ligands and signaling. EMBO J 1998, 17:3797-3806.

177. Lecuit M, Ohayon H, Braun L, Mengaud J, Cossart P: Internalin of Listeria monocytogene with an intact leucine-rich repeat region is sufficient to promote internalization. Infect Immun 1997, 65:5309-5319.

178. Shimoyama Y, Hirohashi S, Hirano S, Noguchi M, Shimosato Y, Takeichi M, Abe O: Cadherin cell-adhesion molecules in human epithelial tissues and carcinomas. Cancer Res 1989, 49:2128-2133.

179. Mengaud J, Ohayon H, Gounon P, Mege RM, Cossart P: E-cadherin is the receptor for internalin, a surface protein required for entry of $L$. monocytogene into epithelial cells. Cell 1996, 84:923-932.

180. Lecuit M, Dramsi S, Gottardi C, Fedor-Chaiken M, Gumbiner B, Cossart P: A single amino acid in E-cadherin responsible for host specificity towards the human pathogen Listeria monocytogene. EMBO J 1999, 18:3956-3963.

181. Bonazzi M, Veiga E, Pizarro-Cerda J, Cossart P: Successive post-translational modifications of E-cadherin are required for $\operatorname{In|A-mediated~}$ internalization of Listeria monocytogene. Cell Microbiol 2008, 10:2208-2222.

182. Seveau S, Pizarro-Cerda J, Cossart P: Molecular mechanisms exploited by Listeria monocytogene during host cell invasion. Microbes Infect 2007, 9:1167-1175.

183. Niessen CM, Leckband D, Yap AS: Tissue organization by cadherin adhesion molecules: dynamic molecular and cellular mechanisms of morphogenetic regulation. Physiol Rev 2011, 91:691-731.

184. Vleminckx K, Vakaet L Jr, Mareel M, Fiers W, van Roy F: Genetic manipulation of E-cadherin expression by epithelial tumor cells reveals an invasion suppressor role. Cell 1991, 66:107-119.

185. Vojtiskova M, Pokorna Z, Draber P: Autoimmune damage to spermatogenesis in rodents immunized with mouse F9 embryonic carcinoma cells. Proc Natl Acad Sci USA 1983, 80:459-461.

186. Ringwald M, Schuh R, Vestweber D, Eistetter H, Lottspeich F, Engel J, Dolz R, Jahnig F, Epplen J, Mayer S: The structure of cell adhesion molecule uvomorulin. Insights into the molecular mechanism of Ca2 +-dependent cell adhesion. EMBO J 1987, 6:3647-3653.

187. Karecla PI, Green SJ, Bowden SJ, Coadwell J, Kilshaw PJ: Identification of a binding site for integrin alphaEbeta7 in the $\mathrm{N}$-terminal domain of $\mathrm{E}$ cadherin. J Biol Chem 1996, 271:30909-30915.

188. Mohan R, Lee B, Panjwani N: Molecular cloning of the E-cadherin CDNAs from rabbit corneal epithelium. Curr Eye Res 1995, 14:1136-1145.

189. Wollert T, Pasche B, Rochon M, Deppenmeier S, van den Heuvel J, Gruber AD, Heinz DW, Lengeling A, Schubert WD: Extending the host range of Listeria monocytogene by rational protein design. Cell 2007, 129:891-902.

190. Monk I, Casey P, Hill C, Gahan C: Directed evolution and targeted mutagenesis to murinize Listeria monocytogene internalin A for enhanced infectivity in the murine oral infection model. BMC Microbiol 2010, 10:318.

191. Lecuit M, Sonnenburg JL, Cossart P, Gordon J: Functional genomic studies of the intestinal response to a foodborne enteropathogen in a humanized gnotobiotic mouse model. J Biol Chem 2007, 282:15065-15072. 
192. Braun L, Ghebrehiwet B, Cossart P: gC1q-R/p32, a C1q-binding protein, is a receptor for the InIB invasion protein of Listeria monocytogene. EMBO J 2000, 19:1458-1466.

193. Shen Y, Naujokas M, Park M, Ireton K: InIB-dependent internalization of Listeri is mediated by the Met receptor tyrosine kinase. Cell 2000, 103:501-510.

194. Jonquieres R, Pizarro-Cerda J, Cossart P: Synergy between the N- and Cterminal domains of InIB for efficient invasion of non-phagocytic cells by Listeria monocytogene. Mol Microbiol 2001, 42:955-965.

195. Cabanes D, Sousa S, Cebria A, Lecuit M, Garcia-del Portillo F, Cossart P: Gp96 is a receptor for a novel Listeria monocytogene virulence factor Vip, a surface protein. EMBO J 2005, 24:2827-2838

196. Nakane A, Minagawa $T$, Kohanawa $M$, Chen $Y$, Sato $H$, Moriyama M, Tsuruoka N: Interactions between endogenous gamma interferon and tumor necrosis factor in host resistance against primary and secondary Listeria monocytogene infections. Infect Immun 1989, 57:3331-3337.

197. Schlech IWF, Chase DP, Badley A: A model of food-borne Listeria monocytogene infection in the Sprague-Dawley rat using gastric inoculation: development and effect of gastric acidity on infective dose. Int J Food Microbiol 1993, 18:15-24.

198. Van Loveren H, Rombout PJ, Wagenaar SS, Walvoort HC, Vos JG: Effects of ozone on the defense to a respiratory Listeria monocytogene infection in the rat. Suppression of macrophage function and cellular immunity and aggravation of histopathology in lung and liver during infection. Toxicol Appl Pharmacol 1988, 94:374-393.

199. Goettsch W, Garssen J, De Klerk A, Herremans TMPT, Dortant P, De Gruijl FR, Van Loveren H: Effects of ultraviolet-B exposure on the resistance to Listeria monocytogene in the rat. Photochem Photobiol 1996, 63:672-679.

200. Michelet C, Leib SL, Bentue-Ferrer D, Tauber MG: Comparative efficacies of antibiotics in a rat model of meningoencephalitis due to Listeria monocytogene. Antimicrob Agents Chemother 1999, 43:1651-1656.

201. Hirose K, Suzuki H, Nishimura H, Mitani A, Washizu J, Matsuguchi T, Yoshikai $Y$ : Interleukin-15 may be responsible for early activation of intestinal intraepithelial lymphocytes after oral infection with Listeria monocytogenes in rats. Infect Immun 1998, 66:5677-5683.

202. Czuprynski CJ, Balish E: Pathogenesis of Listeria monocytogene for gnotobiotic rats. Infect Immun 1981, 32:323-331.

203. Warner TF, Madsen J, Starling J, Wagner RD, Taurog JD, Balish E: Human HLA-B2 gene enhances susceptibility of rats to oral infection by Listeria monocytogene. Am J Pathol 1996, 149:1737-1743.

204. Bortolussi R, Campbell N, Krause V: Dynamics of Listeria monocytogene type $4 \mathrm{~b}$ infection in pregnant and infant rats. Clin Invest Med 1984, 7:273-279

205. Dustoor M, Croft W, Fulton A, Blazkovec A: Bacteriological and histopathological evaluation of guinea pigs after infection with Listeria monocytogene. Infect Immun 1977, 15:916-924

206. Bakardjiev Al, Stacy BA, Fisher SJ, Portnoy DA: Listeriosis in the pregnant guinea pig: a model of vertical transmission. Infect Immun 2004, 72:489-497.

207. Bakardjiev Al, Theriot JA, Portnoy DA: Listeria monocytogene traffics from maternal organs to the placenta and back. PLOS Pathog 2006, 2:e66.

208. Irvin EA, Williams D, Hamler SE, Smith MA: Immunological and pathological changes in the placenta during infection with Listeria monocytogene in pregnant guinea pigs. Reproduct Toxicol 2008, 26:151-155.

209. Cabanes D, Lecuit M, Cossart P: Animal models of Listeria infection. Curr Protoc Microbiol 2008, Chapter 9:Unit9B1.

210. Van Stelten A, Simpson JM, Chen Y, Scott VN, Whiting RC, Ross WH, Nightingale KK: Significant shift in median guinea pig infectious dose shown by an outbreak-associated Listeria monocytogene epidemic clone strain and a strain carrying a premature stop codon mutation in inl. Appl Environ Microbio/ 2011, 77:2479-2487.

211. Roldgaard BB, Andersen JB, Hansen TB, Christensen BB, Licht TR: Comparison of three Listeria monocytogene strains in a guinea-pig model simulating food-borne exposure. FEMS Microbiol Lett 2009, 291:88-94

212. Nightingale KK, Ivy RA, Ho AJ, Fortes ED, Njaa BL, Peters RM, Wiedmann M: inlA premature stop codons are common among Listeria monocytogene isolates from foods and yield virulence-attenuated strains that confer protection against fully virulent strains. Appl Environ Microbiol 2008, 74:6570-6583.
213. Pang H-JE, Matthews KR: Influence of food environment on Listeria monocytogene infection in the guinea pig model. J Food Safety 2006, 26:313-324.

214. Jensen ER, Selvakumar $R$, Shen $H$, Ahmed R, Wettstein FO, Miller JF: Recombinant Listeria monocytogene vaccination eliminates papillomavirus-induced tumors and prevents papilloma formation from viral DNA. J Virol 1997, 71:8467-8474.

215. Larsen SA, Feeley JC, Jones WL: Immune response to Listeria monocytogene in rabbits and humans. Appl Microbiol 1974, 27:1005-1013.

216. Belen Lopez M, Briones V, Fernandez-Garayzabal JF, Vazquez-Boland JA, Garcia JA, Blanco MM, Suarez G, Dominguez L: Serological response in rabbits to Listeria monocytogene after oral or intragastric inoculation. FEMS Immunol Med Microbiol 1993, 7:131-134.

217. Scheld WM, Fletcher DD, Fink FN, Sande MA: Response to therapy in an experimental rabbit model of meningitis due to Listeria monocytogene. J Infect Dis 1979, 140:287-294.

218. Blanot S, Joly MM, Vilde F, Jaubert F, Clement O, Frija G, Berche P: A gerbil model for rhombencephalitis due to Listeria monocytogene. Microb Pathog 1997, 23:39-48.

219. Abram M, Schlüter D, Vuckovic D, Wraber B, Doric M, Deckert M: Murine model of pregnancy-associated Listeria monocytogene infection. FEMS Immunol Med Microbiol 2003, 35:177-182.

220. Guleria I, Pollard JW: The trophoblast is a component of the innate immune system during pregnancy. Nat Med 2000, 6:589-593.

221. Holmlund U, Cebers G, Dahlfors AR, Sandstedt B, Bremme K, Ekstrom ES, Scheynius $A$ : Expression and regulation of the pattern recognition receptors Toll-like receptor-2 and Toll-like receptor-4 in the human placenta. Immunology 2002, 107:145-151.

222. Zuany-Amorim C, Hastewell J, Walker C: Toll-like receptors as potential therapeutic targets for multiple diseases. Nat Rev Drug Discov 2002, 1:797-807.

223. Hamrick TS, Horton JR, Spears PA, Havell EA, Smoak IW, Orndorff PE: Influence of pregnancy on the pathogenesis of listeriosis in mice inoculated intragastrically. Infect Immun 2003, 71:5202-5209.

224. Georgiades P, Ferguson-Smith AC, Burton GJ: Comparative developmental anatomy of the murine and human definitive placentae. Placenta 2002, 23:3-19.

225. Cox B, Kotlyar M, Evangelou Al, Ignatchenko V, Ignatchenko A, Whiteley $K$, Jurisica I, Adamson SL, Rossant J, Kislinger T: Comparative systems biology of human and mouse as a tool to guide the modeling of human placental pathology. Mol Syst Biol 2009, 5:279.

226. Williams D, Dunn S, Richardson A, Frank JF, Smith MA: Time course of fetal tissue invasion by Listeria monocytogene following an oral inoculation in pregnant guinea pigs. J Food Prot 2011, 74:248-253.

227. Irvin EA, Williams D, Voss KA, Smith MA: Listeria monocytogene infection in pregnant guinea pigs is associated with maternal liver necrosis, a decrease in maternal serum TNF-[alpha] concentrations, and an increase in placental apoptosis. Reprod Toxicol 2008, 26:123-129.

228. Jensen A, Williams D, Irvin EA, Gram L, Smith MA: A processing plant persistent strain of Listeria monocytogene crosses the fetoplacental barrier in a pregnant guinea pig model. J Food Prot 2008, 71:1028-1034

229. Klink M, Rudnicka W: Listeria monocytogene infection in pregnant mice: abnormalities in the function of non-adherent accessory light density dendritic cells. FEMS Immunol Med Microbiol 1995, 12:143-152.

230. Nakane A, Minagawa T, Yasuda I: Induction of alpha/beta interferon and gamma interferon in mice infected with Listeria monocytogene during pregnancy. Infect Immun 1985, 50:877-880.

231. Ito Si, Ishii KJ, Shirota H, Klinman DM: CpG Oligodeoxynucleotides improve the survival of pregnant and fetal mice following Listeria monocytogene infection. Infect Immun 2004, 72:3543-3548.

232. Abram M, Dorić M: Primary Listeria monocytogene infection in gestating mice. Folia Microbiol 1997, 42:65-71

233. Gardner ID, Remington JS: Age-related decline in the resistance of mice to infection with intracellular pathogens. Infect Immu 1977, 16:593-598.

234. Antonini JM, Roberts JR, Clarke RW, Yang HM, Barger MW, Ma JYC, Weissman DN: Effect of age on respiratory defense mechanisms. Chest 2001, 120:240-249

235. Bruce D, Whitcomb JP, August A, McDowell MA, Cantorna MT: Elevated non specific immunity and normal Listeri clearance in young and old vitamin D receptor knockout mice. Int Immunol 2009, 21:113-122. 
236. Patel PJ: Aging and antimicrobial immunity. Lowered efficiency of protective $T$ cells as a contributing factor for the decreased resistance of senescent mice to listeriosis. J Exp Med 1982, 155:1870-1875.

237. Lovik M, North R: Effect of aging on antimicrobial immunity: old mice display a normal capacity for generating protective $T$ cells and immunologic memory in response to infection with Listeria monocytogene. J Immunol 1985, 135:3479-3486.

238. Louria DB, Lavenhar MA, Kaminski T, Buse M, Kaplan M: Staphylococca infections in aging mice. J Gerontol 1986, 41:718-722.

239. Bradley SF, Kauffman CA: Aging and the response to Salmonell infection. Exp Gerontol 1990, 25:75-80

240. Miller RA, Nadon NL: Principles of animal use for gerontological research. J Gerontol A Biol Sci Med Sci 2000, 55:B117-B123.

241. Flurkey K, Currer JM: Pitfalls of animal model systems in ageing research. Best Pract Res Clin Endocrinol Metab 2004, 18:407-421.

242. Louria DB, Sen P, Buse M: Age-dependent differences in outcome of infections, with special reference to experiments in mice. J Am Geriatr Soc 1982, 30:769-773.

243. Wu D, Meydani SN: Age-associated changes in immune and inflammatory responses: impact of vitamin E intervention. J Leukoc Biol 2008, 84:900-914.

244. Brouwer A, Knook DL: The reticuloendothelial system and aging: a review. Mech Ageing Dev 1983, 21:205-228.

245. Tateda K, Matsumoto T, Miyazaki S, Yamaguchi K: Lipopolysaccharideinduced lethality and cytokine production in aged mice. Infect Immun 1996, 64:769-774.

246. Gardner ID: The effect of aging on susceptibility to infection. Rev Infect Dis 1980, 2:801-810.

247. Patel PJ: Aging and antimicrobial immunity. Impaired production of mediator T cells as a basis for the decreased resistance of senescent mice to listeriosis. J Exp Med 1981, 154:821-831, 154.

248. Wu WH: Influence of immunoenhancement by dietary vitamin $E$ supplementation on the development of Listeria monocytogenes infection in aged and young guinea pigs New Brunswick: Rutgers University; 2009.

249. Gervais F, Patel P, Skamene E: Increased natural resistance to Listeria monocytogene in senescent mice correlates with enhanced macrophage bactericidal activity. J Gerontol 1988, 43:B152-B156.

250. Kress C, Vandormael-Pournin S, Baldacci P, Cohen-Tannoudji M, Babinet C. Nonpermissiveness for mouse embryonic stem (ES) cell derivation circumvented by a single backcross to $129 /$ Sv strain: establishment of ES cell lines bearing the Omd conditional lethal mutation. Mamm Genome 1998, 9:998-1001.

251. Lallemand $Y$, Luria $V$, Haffner-Krausz R, Lonai P: Maternally expressed PGKCre transgene as a tool for early and uniform activation of the Cre sitespecific recombinase. Transgenic Res 1998, 7:105-112.

doi:10.1186/1297-9716-43-18

Cite this article as: Hoelzer et al: Animal models of listeriosis: a

comparative review of the current state of the art and lessons learned. Veterinary Research 2012 43:18.

\section{Submit your next manuscript to BioMed Central and take full advantage of:}

- Convenient online submission

- Thorough peer review

- No space constraints or color figure charges

- Immediate publication on acceptance

- Inclusion in PubMed, CAS, Scopus and Google Scholar

- Research which is freely available for redistribution

Submit your manuscript at www.biomedcentral.com/submit
Biomed Central 